\title{
A PRESENÇA BRASILEIRA NA AGRICULTURA MOÇAMBICANA E OS PARADIGMAS DO MODELO AGRÁRIO EM QUESTÃO: UM OLHAR GEOGRÁFICO SOBRE O PROSAVANA
}

\author{
THE BRAZILIAN PRESENCE IN MOZAMBICAN AGRICULTURE AND THE PARADIGMS OF THE AGRARIAN MODEL IN \\ QUESTION: A GEOGRAPHIC LOOK AT PROSAVANA
}

\section{RESUMO}

O presente artigo analisa o processo de territorialização do ProSAVANA e os desdobramentos socioterritoriais do ProSAVANA no Corredor de Nacala. Da análise feita, compreende-se que o ProSAVANA é um programa que engendra a monopolização do território pelo capital para produção de commodities de interesse do mercado global. $O$ interesse na verdade é o de garantir acumulação ampliada do capital à escala global a partir do Corredor de Nacala, usando os territórios comunitários e sua gente no processo de produtivo. Por de traz da ideia da modernidade e do discurso produtivista e desenvolvimentista, o ProSAVANA esconde o seu caráter rentista, expropriador, explorador, excludente, predador dos recursos naturais dentre outras barbáries no campo. A concentração de terras, da riqueza e da renda nas mãos de pequenos grupos, estão entre os impactos negativos do modelo proposto pelo ProSAVANA para a modernização da agricultura no Corredor de Nacala. Os conflitos socioambientais são inevitável por onde o agronegócio se territorializa no campo. O ProSAVANA é também uma ameaça ao modo camponês de fazer agricultura que predomina nesta região. Ameaça também a soberania alimentar dos povos locais, e consequentemente, a segurança alimentar e nutricional. As lutas e resistências camponesas e dos movimentos sociais contra sua implementação efetiva no Corredor de Nacala, são legítimas, sobretudo, olhando para o caráter desigual, contraditório e perverso do agronegócio por onde se territorializa no campo.

Palavras-chave: ProSAVANA; Corredor de Nacala; Soberania Alimentar; Segurança Alimentar; Conflitos Socioambientais.

\section{ABSTRACT}

This article analyzes ProSAVANA's territorialization process and ProSAVANA's socio-territorial developments in the Nacala Corridor. From the analysis made, it is understood that ProSAVANA is a program that engenders the monopolization of the territory by capital for the production of commodities of interest to the global market. The interest in fact is to guarantee an expanded accumulation of capital on a global scale from the Nacala Corridor, using community territories and their people in the production process. Behind the idea of modernity and the productivist and developmentalist discourse, ProSAVANA hides its rentier, expropriating, exploiting, exclusionary nature, predator of natural resources among other barbarism in the countryside. The concentration of land, wealth and income in the hands of small groups, are among the negative impacts of the model proposed by ProSAVANA for the modernization of agriculture in the Nacala Corridor. Socio-environmental conflicts are inevitable where agribusiness is territorialized in the countryside. ProSAVANA is also a threat to the peasant way of farming that prevails in this region. It also threatens the food sovereignty of local people and, consequently, food and nutritional security. The struggles and resistance of peasants and social movements against their effective implementation in the Nacala Corridor are legitimate, above all, looking at the uneven, contradictory and perverse character of agribusiness through which it is territorialized in the countryside.

Keywords: ProSAVANA; Nacala Corridor; Food Sovereignty; Food security; Socioenvironmental conflicts.

\section{(D) Lucas Atanásio Catsossa a, b}

a Universidade Púnguè (UniPúnguè), Tete, Moçambique

${ }^{\mathrm{b}}$ Universidade Católica de Moçambique (UCM), Tete, Moçambique

DOI: $10.12957 /$ geouerj.2020.53913

Correpondência: lucascatsossauem@gmail.com Recebido em: 20 mai. 2019 Revisado em: 15 jan 2020 Aceito em: 13 fev. 2020 
"Quando os missionários chegaram [à África], os africanos tinham a terra e os missionários a bíblia. Ensinaram-nos a orar com olhos fechados. Quando os abrimos eles [os missionários] tinham a terra e nós [os africanos] a bíblia».

Jomo Kenyatta

"Anteriormente, as grandes nações mandavam seus exércitos para conquista territórios e o nome disto era colonização. Hoje, as grandes nações mandam suas multinacionais conquistar mercados e o nome disto é globalização»

Milton Santos

"A questão agrária é, antes de outras coisas, um problema [de soberania] territorial. A procura de novos territórios para a expansão da agricultura tem hoje uma nova característica. Empresas e governos de diversos países [...] riscos em capital, mas pobres em alimentos [...] estão arrendando e comprando [...] gigantescas áreas de terras. [...] este processo de exploração não é novo, o que é novidade é que além de empresas, os governos estão mais envolvidos nos acordos que reforçam o neocolonialismo e consequentemente, aprofundam as formas de dependência».

Fernandes (2009)

"O mundo está a mudar e a lusofonia também; o eurocentrismo que moldou décadas de relações Norte-Sul está a ser interceptado por um diálogo SUL-SUL que não deixará de cair, no seio da Comunidade dos Países da Língua Portuguesa (CPLP), relacionamentos mais abertos e competitivos, logo mais complexos. [...]. Este novo ciclo econômico é mercado pela forte presença de empresas brasileiras na área de mineira, exploração do gás natural, petróleo e, imprevisivelmente, até na

agricultura»

Jacinto (2014)

\section{INTRODUÇÃO}

O texto que está em (e/ou nas) suas mãos, trata da presença brasileira na agricultura moçambicana, em que procuro analisar o ProSAVANA, um programa que surge no âmbito das relações bilaterais entre Brasil e Moçambique. Embora o professor Edvaldo tenha me convidado a escrever um texto que fosse a contar a minha experiência obtida no âmbito do projeto de intercâmbio entre a Universidade Federal da Grande Dourados (UFGD/Brasil) e a Universidade Eduardo Mondlane (UEM/Moçambique), em 2014, decidi analisar este programa. Por isso, não se trata de um texto que relata da importância deste intercâmbio para a minha trajetória enquanto pesquisador, embora tudo tenha começado a partir dele. No convite endereçado a minha pessoa via correio eletrônico (e-mail), o Professor Edvaldo dizia o seguinte e passo a citar: 
Talvez alguém se pergunte, mas porque escolheu outra temática se no convite solicitava que fosse um texto que relatasse a importância da projeto de intercâmbio acadêmico firmado entre a UFGD/Brasil e a UEM/Moçambique, tanto na vida dele como na sua trajetória enquanto pesquisador. Não pretendo com isso, dizer que este intercâmbio não significou nada na minha vida. Pelo contrário, sob ponto de vista de minha formação acadêmica e como pesquisador, ele foi determinante. Viver em trânsito entre as fronteiras de Moçambique e do Brasil, foi uma experiência única enquanto geógrafo e isto, só foi possível por meio deste intercâmbio. Quero desde já, agradecer ao professor Edvaldo, na altura coordenador do projeto de intercâmbio do lado brasileiro, pela atenção e apoio material e moral que me deu.

Por sua vez, agradeço-Ihe pela orientação no mestrado, pois quando identifiquei o ProSAVANA como objeto de pesquisa, foi com ele que desenvolvi cientificamente esta temática. Agradeço-lhe também pela sua generosidade, pois graças ao seu esforço, incentivo, apoio moral e material incondicional e da sua esposa, Prof.a. Dra. Silvana Moretti, sem, no entanto, retirar o papel desempenhado pela Prof.a. Dra. Marisa de Fátima Lomba de Farias neste processo que consegui continuar com os meus estudos, desde o nível de mestrado e de doutorado na UFGD, neste último, sob orientação do Prof. Dr. João Edmilson Fabrini, a quem também agradeço. Não pretendo com isso, trazer todas as suas qualidades enquanto um ser humano, pois levaria muito tempo e ocuparia muitas páginas para descrevê-las. No entanto, deixarei esse desafio para uma outra ocasião!

Do lado moçambicano, agradeço também a Prof.a. Drạ Inês Macamo Raimundo, geógrafa e professora da UEM, que na altura era coordenadora do projeto de intercâmbio, pela sua generosidade, apoio moral e, sobretudo, pela oportunidade que me concedeu para participar deste intercâmbio no meio de vários estudantes do curso de Geografia naquele ano (de 2014). Um agradecimento especial vai para os membros (e colaboradores) do Grupo de Pesquisa Território e Ambiente (GTA/FCH/UFGD), o qual sou colaborador estrangeiro de pesquisa desde Maio de 2014, pelos momentos, ensinamentos e debates que foram importantes na construção do discurso geográfico e também na compreensão de certos fenômenos geográficos além fronteira.

A escolha o ProSAVANA como objeto de análise neste texto, tem haver sim com a trajetória acadêmica enquanto pesquisador. Foi a partir desta temática que me tornei pesquisador. E mais, esta temática está intrinsecamente ligado com a experiência que tive durante o intercâmbio no Brasil, sobretudo, na UFGD. Mais tarde, a temática aqui escolhida para ser analisada, foi objeto de estudo, sobretudo, quando ingressei no mestrado, na UFGD em 2015, aonde o professor Edvaldo foi meu orientador, no qual agradeço pela sua orientação. $O$ interesse pelo ProSAVANA, surge no meio de uma conversa que (man)tive com a Professor Silvana, sua esposa, a quem eu agradeço pela sua contribuição incondicional neste processo. 
As grandes plantações de soja, de cana-de-açúcar e de milho que vi durante o intercâmbio, nas visitas de campo que realizei em alguns lugares no Estado de Mato Grosso do Sul, tinham em algum momento me "fascinado". Sendo geógrafa, pesquisadora e moradora do Estado do Mato Grosso do Sul por muitos anos, a Professora Silvana, me chamou atenção, no sentido de olhar com mais atenção o que tanto me fascinava. Numa das pesagens da nossa conversa, a Professora Silvana, disse para que não me iludisse com o que via no campo brasileiro, destacando que dentro daquelas plantações (monoculturas), havia algo "oculto" e "ruim", que era isso que oprimia os povo e que era responsável por tantas outras barbáries.

Na verdade, fui abrindo olhos para enxergar as coisas, daí que fui percebendo as contradições. No entanto, foi quando percebi por meio de leituras de livros, teses e dissertações e das conversas com colegas e professores programa de graduação e da pós-graduação da UFGD e não só, que a desumanidade a qual os povos indígenas eram condenados a viver, enquanto são tidos como donos das terras, algumas das quais, são usadas pelos ruralistas do agronegócio, faz parte destas contradições geradas pelas monoculturas que me fascinavam.

Mas como se dizia que havia muita coisa oculta naquelas plantações que tanto me fascinavam, fiquei ainda curioso em saber o que era. Quando regressei para Moçambique e ao fazer uma avaliação da viagem e de ter participado do intercâmbio acadêmico, sempre me perguntava: mas, porque a Professora Silvana disse que naquelas plantações havia muita coisa "oculta" e "ruim"? O que será? É aqui, onde tudo começa, sobretudo, a minha trajetória enquanto pesquisador. Chegado a Moçambique, dias depois, constatei que estava a decorrer um debate (in)tenso em volta do ProSAVANA.

As organizações da sociedade civil, na sua maioria, constituídas por organizações camponesas, feministas e ligados aos direitos humanos e a proteção do meio ambiente, estavam a travar uma batalha com os executores do ProSAVANA. Estas organizações diziam "Não ao ProSAVANA", denunciando-o que era uma ameaça agricultura camponesas e a biodiversidade em Moçambique. Estas organizações dizia-se ainda que tratava-se de um programa já implementado no Brasil, o PRODECER (Programa de Desenvolvimento dos Cerrados). A partir daqui, começaram a surgir outras perguntas, como, por exemplo, que programa é esse que é acusado de ser uma ameaça a agricultura camponesa a biodiversidade em Moçambique? Que programa é esse que vem do Brasil?

Isso me fazia pensar na conversa que tive com a professora Silvana durante o intercâmbio acadêmico. Foi daí que decidi entrar no google para ver se encontrava alguma informação. Quando abri a página do google, primeiro, escrevi a palavra ProSAVANA, apareceram várias informações sobre este programa, sendo na sua maior parte, denúncias feitas por organizações da sociedade civil, as mesmas que me referi 
anteriormente. Mais adiante, descobri que, as denúncias em torno do ProSAVANA, não aconteciam apenas em Moçambique, mas também, no Brasil.

No caso do Brasil, os movimentos sociais (composto pelo MST [Movimento dos Trabalhadores Rurais Sem-Terra], a CPT [Comissão Pastoral da Terra], a FASE/Brasil, o [Movimento de Pequenos Agricultores], só para citar alguns exemplos) temiam a reprodução dos conflitos socioambientais, enfim era a tal barbárie que a professora Silvana referiu quando conversamos durante o intercâmbio em Dourados. Em segundo lugar, escrevi a palavra PRODECER, e vieram várias informações, entre elas, artigos científicos. Este criticavam também este programa, considerando-o de ter tido impactos socioambientais negativos no cerrado brasileiro durante sua implementação.

De referir que, no caso do ProSAVANA, já havia alguns artigos científicos publicados, de autores moçambicanos, brasileiros e japoneses, aonde denunciavam este programa. Nessa altura já haviam também cartas abertas publicadas das organizações contestando este programa em Moçambique, destacando o seu sentido perverso. Também haviam sido publicados alguns artigos em jornais moçambicanos, elaborados por ativistas sociais brasileiros, o caso da Fátima de Mello, da FASE/Brasil que criticava o ProSAVANA, alegando que era um programa excludente e que poderia reproduzir as contradições do PRODECER caracterizadas pela expropriação e expulsão dos camponeses no campo e de degradação ambiental no cerrado brasileiro.

Isto tudo, trazia em mim, a curiosidade de querer compreender o porquê da conflitualidade entre os executores do ProSAVANA (Brasil, Japão e Moçambique) com as organizações da sociedade civil, movimentos sociais, associações de camponeses nacionais e internacionais. Estas e outras questões, fizeram com que mais tarde, colocasse o ProSAVANA como objeto de estudo. Foi assim que passei a estudar ProSAVANA visando compreender a geografia que pode ser produzida na savana moçambicana em caso da sua implementação efetiva. Contudo, o texto em vossas mãos, faz parte da minha contribuição ao debate em torno da geopolítica da questão agrária mundial, no qual o ProSAVANA se insere, caracterizada pela deslocamento de fronteiras agrícolas de uma região do mundo para outro, visando ocupar extensas áreas de terras para a produção de commodities de interesse do mercado global.

Este texto está dividido em três seções. Na primeira seção, discute as relações bilaterais entre Brasil e Moçambique, pois o ProSAVANA surge e, é implementado nesse contexto. Na segunda seção, procura-se analisar rigorosamente o ProSAVANA como forma de trazer as possíveis contradições. Para tal, será utilizada uma bibliografia que fala do agronegócio enquanto modelo agrário/agrícola dominante no campo e também que trata sobre os desdobramentos do seu "primogênito" do cerrado brasileiro: o PRODECER. Na terceira e última seção, descreve-se as ações dos movimentos sociais e dos camponeses na luta contra o ProSAVANA em Moçambique. 
Cooperação Sul-Sul entre Brasil e Moçambique: a base para a compreensão do ProSAVANA

\begin{abstract}
"Moçambique é o maior beneficiário da cooperação do Brasil no exterior, não somente em África, mas também no mundo inteiro. Nós temos 40 projetos em andamento em diversas áreas [...] e temos também a cooperação agrícola [...] do programa ProSAVANA».

(Rodrigo Soares, ex-embaixador do Brasil em Moçambique).
\end{abstract}

O ProSAVANA, enquanto programa agrícola, visa empreender a modernização da savana moçambicana, não pode ser visto fora dos meandros do paradigma da Cooperação Sul-Sul. Antes de avançar com um olhar mais aprofundado sobre o que determinou a sua territorialização, é importante revisitar as relações de cooperação entre Moçambique e Brasil inseridas no paradigma da Cooperação Sul-Sul.

As relações de cooperação entre Brasil e Moçambique, datam desde a década de 1970, isto é, logo após a proclamação da independência de Moçambique em 1975. Inicialmente, a presença brasileira em Moçambique foi caracterizada por uma ligeira timidez, olhando para a quantidade de investimento alocado (CHICHAVA \& DÚRAN, 2013). Como foi realçado anteriormente, até a data do início das relações de cooperação entre os dois países, o paradigma da Cooperação Sul-Sul era antes de se tornar um fenômeno, o que quer dizer que, ela é uma reinvenção do século XXI, inserida no atual contexto da globalização enquanto "o ápice do processo de internacionalização do mundo capitalista" (SANTOS, 2013, p. 23).

Ao ser reinventado, o paradigma da Cooperação Sul-Sul enquanto prioridade da Política Externa Brasileira na sua inserção em Moçambique e no continente africano, no geral, a ideia principal era "descentralizar as ações para que os países desenvolvam sem depender exclusivamente da Cooperação NorteSul, notadamente, pautada na exploração" (MELO, OLIVEIRA \& BARBOSA JR., 2018, p. 85). As relações de cooperação Brasil-Moçambique começam a ganhar dinamismo na primeira década do século XXI, sobretudo, com a chegada de Luiz Inácio Lula da Silva ao poder em 2003 por via do Partido dos Trabalhadores (PT).

É através do governo Lula (2003-2010) que a África e Moçambique, em particular, começam a notabilizar-se naquilo que era as ações do Brasil em termos de investimentos. A eleição de Dilma Rousseff em 2011, deu continuidade à política externa brasileira paradigmática iniciada pelo seu antecessor em relação ao continente africano e Moçambique, em particular. Além de abertura de novas representações diplomáticas, as viagens feitas pelos antigos presidentes do Brasil, Lula e Dilma Rousseff, respectivamente, são, portanto, a prova inequívoca do interesse do Brasil na África e, em Moçambique, duma forma particular.

Importa realçar que, as relações de cooperação entre Brasil e o continente africano e Moçambique, em particular, voltaram a esfriar novamente com a chegada ao poder de Michael Temer via golpe parlamentar, após derrubar Dilma Rousseff por meio do Impeatchment em Agosto de 2016, no âmbito das chamadas pedaladas fiscais, transformadas no crime de responsabilidade social. Logo após chegar ao poder, Michael 
Temer despachou uma liminar que cancelava o envio de três (3) aviões do tipo tucano ao governo moçambicano, foram cancelados, e os investimentos que eram feitos para a construção da Barragem Moamba Major também não escaparam.

Um dos únicos setores que o governo brasileiro sob gestão de Michel Temer não abandonou foi o de agricultura, pois como se sabe, é onde foram investidos milhões de dólares para a implementação do programa ProSAVANA. No entanto, de 2016 até 2017, as viagens presidenciais não aconteceram como era durante os governos "petistas" e isto, ocasionou uma mudança em termos geopolíticos, sobretudo, na forma como Política Externa Brasileira passou a ser executada pelo governo Temer, por direcioná-la para os países ricos, entre eles, os EUA, alguns países europeus, etc.

Tabela 1. Visitas de altos dignitários brasileiros e moçambicanos. Fonte: Chichava (2017).

\begin{tabular}{lll}
\hline Anos & Visitas de altos dignitários brasileiros a Moçambique & Visitas de altos dignitários moçambicanos ao Brasil \\
\hline $\mathbf{2 0 0 3}$ & Luís Inácio Lula da Silva (Presidente) & Joaquim Alberto Chissano (Presidente) \\
$\mathbf{2 0 0 4}$ & & Armando Emílio Guebuza (Presidente) \\
$\mathbf{2 0 0 7}$ & & \\
$\mathbf{2 0 0 8}$ & Luís Inácio Lula da Silva (Presidente) & Armando Emílio Guebuza (Presidente) \\
$\mathbf{2 0 0 9}$ & & \\
$\mathbf{2 0 1 0}$ & Luís Inácio Lula da Silva (Presidente) & Aires Ali (Primeiro-Ministro) \\
$\mathbf{2 0 1 1}$ & Dilma Rousseff (Presidente) & \\
$\mathbf{2 0 1 2}$ & Michael Temer (Vice-Presidente) & \\
$\mathbf{2 0 1 5}$ & Mauro Vieira (Ministro das Relações Exteriores) & \\
$\mathbf{2 0 1 7}$ & Aloysio Nunes Ferreira (Ministro das relações Exteriores) & \\
\hline
\end{tabular}

Nota: Organizado pelo autor.

Como se pode ver na tabela 1, após o golpe parlamentar perpetrado pela "turma" de Michel Temer (que fez deste, presidente do Brasil), as autoridades brasileiras visitaram

Moçambique uma vez e isso aconteceu em 2017. O distanciamento do Brasil do continente africano e com Moçambique, em particular, continuou a verificar-se. Essa situação piorou ainda mais com a entrada no poder do candidato da extrema direta, Jair Bolsonaro, em janeiro de 2019.

A política externa de Jair Bolsonaro, mantém fortes laços com os EUA. Além de bater continência, Jair Bolsonaro é acusado de estar a "vender" a soberania brasileira, ao entregar quase um pouco de tudo, sobretudo, recursos naturais, com destaque para o pré-sal e a Amazônia, para serem geridos, controlados e explorados com os "gringos" (norte-americanos), situação que torna o Brasil, que já foi uma potência latinoamericano, a ser subalterno a hegemonia dos EUA. Dito de outra maneira, com Jair Bolsonaro, o Brasil está transformar-se, diga-se de passagem, num "quintal” de experiência do neoliberalismo norte-americano. 
A diferença de Jair Bolsonaro que viajou pelo Ocidente e o Oriente Médio, sobretudo, quando chegou ao poder em 2019, a primeira coisa que Lula fez quando chegou ao poder em 2003, foi viajar pela África, rompendo assim com a "velha" política externa brasileira que valorizava apenas os países ocidentais com destaque para os EUA e alguns da Europa. Para Lula, havia necessidade de diversificar a Política Externa Brasileira, e a África, era para ele um território fértil para tal propósito.

Após chegar ao poder em 2003, o governo Lula frisou que a cooperação do Brasil com Moçambique, seria pautada pela solidariedade entre os povos, deixando claro que não havia interesses econômicos, sobretudo, na contraparte brasileira. Em outras palavras, supostamente a Política Externa Brasileira para com as "nações" africanas, não tinha como fins a retirada de dividendo, mas sim, seria guiada com base na solidariedade dos povos, sendo Brasil o mais solidário neste processo. Através do governo Lula, o Brasil reconhece pela primeira vez, que havia uma "dívida histórica" por pagar aos países (e aos povos) africanos e de Moçambique, em particular. Essa "dívida histórica”, a qual o governo Lula se referia, deve-se a crueldade, humilhação e violência que muitos africanos e moçambicanos, em particular, foram obrigados a passar no "Brasil colônia", pois eram usados como escravos em vários setores de atividades, sobretudo, na agricultura e construção.

Contraditoriamente, Jair Bolsonaro, é citado que durante a campanha eleitoral em 2018, afirmou que o Brasil não tinha nenhuma dívida histórica com a África. Os pronunciamentos atribuídos a Jair Bolsonaro, foram feitos numa situação em que há estudos que confirmam que muitos africanos de Moçambique e não só, foram escravizados de variadíssimas formas e da maneira mais cruel e desumana, tanto na construção como nas plantações no Brasil. Esses estudos, apontam ainda que havia os navios negreiros brasileiros que carregavam os moçambicanos para serem usados como escravos no Brasil e, ancoravam-se na llha de Moçambique, a primeira capital de Moçambique. Cachat (2018) revela que:

Na Ilha de Moçambique, o tráfico de escravos com destino ao Brasil começa, portanto, em 1643, mas ainda não é feito de maneira sistemática na altura. Grandes fileiras são organizadas no continente, em Mossuril, que se torna base na base desse comércio (CACHAT, 2018, p. 36).

Com a sua entrada no poder em 2003, Lula mostrou fortes sinais de "solidariedade" com as "nações" africanas. Moçambique é apenas um exemplo, desta aparente solidariedade do Brasil com África. A fábrica de produção de antirretrovirais (medicamente para atenuar/combater o HIV/SIDA), a incorporação de Moçambique no programa de cooperação educacional - PEC-PG (Programa de Convênio de Estudante de PósGraduação) para estudantes moçambicanos frequentarem mestrados e doutorados, foram alguns dos sinais desta aparente solidariedade do governo Lula. Com a entrada do governo Dilma Rousseff, essas políticas educacionais no contexto da cooperação internacional, continuaram, mas acabaram por ser ameaçadas com a chegada de Michel Temer no poder. Mais tarde, com Jair Bolsonaro no poder, milhares de bolsas de estudos, 
foram apenas canceladas, afetando milhões de estudado financiados pelas principais agências de fomento, CNPq e CAPES, respectivamente.

Há, no entanto, possibilidades que estes cortes tenham afetado também os programas acadêmicos no âmbito da cooperação internacional, como, por exemplo, o PEC-G e PEC-PEG, respetivamente. Durante os governos petistas, o Brasil revelou a sua verdadeira face, não apenas em Moçambique, mas também em quase todo o continente africano, onde direcionava o seu investimento. Por de trás do discurso solidário e a aparente preocupação com a "acabar" com a fome e a miséria em Moçambique, revelou que havia uma racionalidade econômica.

A realidade mostrou que o Brasil a partir de África e de Moçambique em particular, queria transformarse num ator na geopolítica internacional tal como acontece com os países do hemisfério norte. No entanto, era uma disputa pelo controlo da África e dos recursos naturais junto com os países poderosos do Ocidente, sobretudo, os EUA. O preço desta aparente ascensão do Brasil via BRICS como uma nova potência do sul global foi alto, sendo que mais tarde, as tensões de territorialidades no campo geopolítico aumentaram, já que este país latino-americano representava uma ameaça aos interesses da classe dominante, sobretudo, do Ocidente - , os EUA.

Adicionado ao mau ambiente político e econômico no âmbito nacional e internacional, o que o geógrafo britânico, David Harvey considerou de "Loucura da razão econômica», esta situação contribuiu favoravelmente para a queda da presidente Dilma Rousseff no poder em 2016. Os interesses do Brasil em Moçambique, são múltiplos, diversificados e complexos, pois implantaram-se os grupos geoeconômicos brasileiros durante os governos petistas e pode-se destacar os seguintes: a mineradora Vale Moçambique (exVale do Rio Doce), a Correia Camargo, a Odebrecht, a Fio-Cruz, a Eletrobrás, a Petrobras, a EMBRAPA (Empresa Brasileira de Pesquisa Agropecuária).

A EMBRAER (Empresa Brasileira Aeronáutica), também começou a fazer negócios em Moçambique, tendo comercializado por meio de esquemas de corrupção seus aviões para às Linhas Áreas de Moçambique (LAM). Importa realçar ainda que, no caso das construtoras, algumas tiveram financiamento do BNDES (Banco Nacional de Desenvolvimento Econômico e Social) para a execução das suas atividades. Além disso, muitos empresários singulares se instalaram em Moçambique em vários ramos de atividades por onde fazem seus negócios. Insinuando, Jacinto (2014) remata:

Não terão sido estas razões que motivaram a escolha de Moçambique a última visita do presidente Lula da Silva a um país estrangeiro. Além daqueles negócios também não é despiciendo ter presente apoios técnicos brasileiros na implementação da celebrada bolsa família, ou qualquer outro seu sucedâneo, que ajude a mitigar a fome e a pobreza, nem o elevado número de bolsas atribuídas a estudantes moçambicanos para complementar a sua formação superior no Brasil. A omnipresença deste país não deixará um certo modelo econômico e social que vai fazendo caminho, sugerindo outras comparações, 
mesmo que simbólicas, com a progressão assustadora da violência urbana (raptos, p. ex) (JACINTO, 2014, p. 95).

Sem rodeio e duma forma contundente, Aguiar e Pacheco (2015) rematam:

[...] a evolução da política externa brasileira - e de suas diretivas para a cooperação - não manteve uma trajetória linear nos últimos anos, tendo-se observado uma mudança fundamental do governo Lula para o governo Dilma com forte reflexo da iniciativa da política no front externo. [...]. No caso da África, a política externa brasileira se traduziu em programas que orientavam os diversos agentes - públicos, privados, programas de assistência técnica, humanitária, diálogos políticos - em uma direção: aumentar a presença política e econômica do Brasil no continente. No governo Dilma, o reflexo da iniciativa na política externa acabou por produzir um vazio, que resultou em um alargamento do espaço para atuação do setor privado sem que houvesse diretrizes norteadores (AGUIAR \& PACHECO, 2015, p. 14 15).

O carisma de Lula reconhecido mundialmente, adicionado ao suposto sucesso das políticas públicas implementadas durante a sua governação, foi também determinante para que o Brasil avançasse com suas iniciativas para Moçambique. Agricultura é que teve maior destaque no que tange ao investimento brasileiro em Moçambique. Por exemplo, até Março de 2016, o antigo embaixador brasileiro, Rodrigo Soares, fez referência que em Moçambique, havia cerca 40 projetos brasileiros em andamento, incluindo o ProSAVANA no setor da agricultura (cf. CATSOSSA, 2017).

No caso da agricultura, "o Brasil comprometeu-se multi e bilateralmente a ajudar Moçambique a alcançar a revolução verde" (CHICHAVA \& DÚRAN, 2013, p. 399, grifo meu). Se em termos socioambientais a revolução verde significou a reprodução da fome e da miséria, a expropriação e expulsão dos camponeses das suas terras e a pilhagem dos recursos naturais e, consequentemente, a degradação ambiental e entre outras barbáries no próprio Brasil, como fazer com que seja um sucesso em Moçambique? É o que se verá a seguir.

\section{ProSAVANA: a modernidade e colonialidade camuflada no discurso produtivista e desenvolvimentista}

$$
\begin{array}{r}
\text { "A ideia de "Mundo Novo", bem como toda a obsessão pelo novo, que tanto marcará a chamada } \\
\text { Modernidade, o imaginário europeu ocidental desde o nascimento e o colonialismo, deveu-se à } \\
\text { necessidade de afirmação frente ao "Mundo Antigo - o Oriente [...] como centro geopolítico e cultural } \\
\text { do mundo». } \\
\text { Haesbeart e Porto-Gonçalves (2006). }
\end{array}
$$

«A geografia mundial sofrerá importantes mudanças, mantendo, entretanto, a estrutura modernocolonial». Porto-Gonçalves (2017)

Antes de fazer uma análise mais aprofundada do ProSAVANA, torna-se importante, apresentar e fazer uma caracterização socioeconômica do território identificado para a sua implementação no Corredor de Nacala. Este programa, resulta duma cooperação trilateral entre Moçambique, Brasil e Moçambique, visando 
a modernização agrícola das savanas moçambicanas, sendo que o acordo para a sua implementação foi assinada em Setembro de 2009.

Documentos oficiais revelam que o ProSAVANA inspira-se no PRODECER (Programa de Desenvolvimento dos Cerrados), implementado no cerrado brasileiro, a partir dos finais da segunda metade de 1990, numa cooperação bilateral entre Brasil e Japão. Há estudos que apontam que Moçambique apenas foi identificado como beneficiário deste programa e que não participou da sua elaboração. Dito de outra forma, Brasil e Japão são os verdadeiros responsáveis pela concepção e elaboração do ProSAVANA, sendo que apenas Moçambique foi identificado como país beneficiário da iniciativa (cf. FUNANDACLASSE, 2013). Este programa ocupa uma área estimada em cerca de 14,5 milhões de hectares de terras.

Figura 1. Território do ProSAVANA no Corredor de Nacala/Moçambique

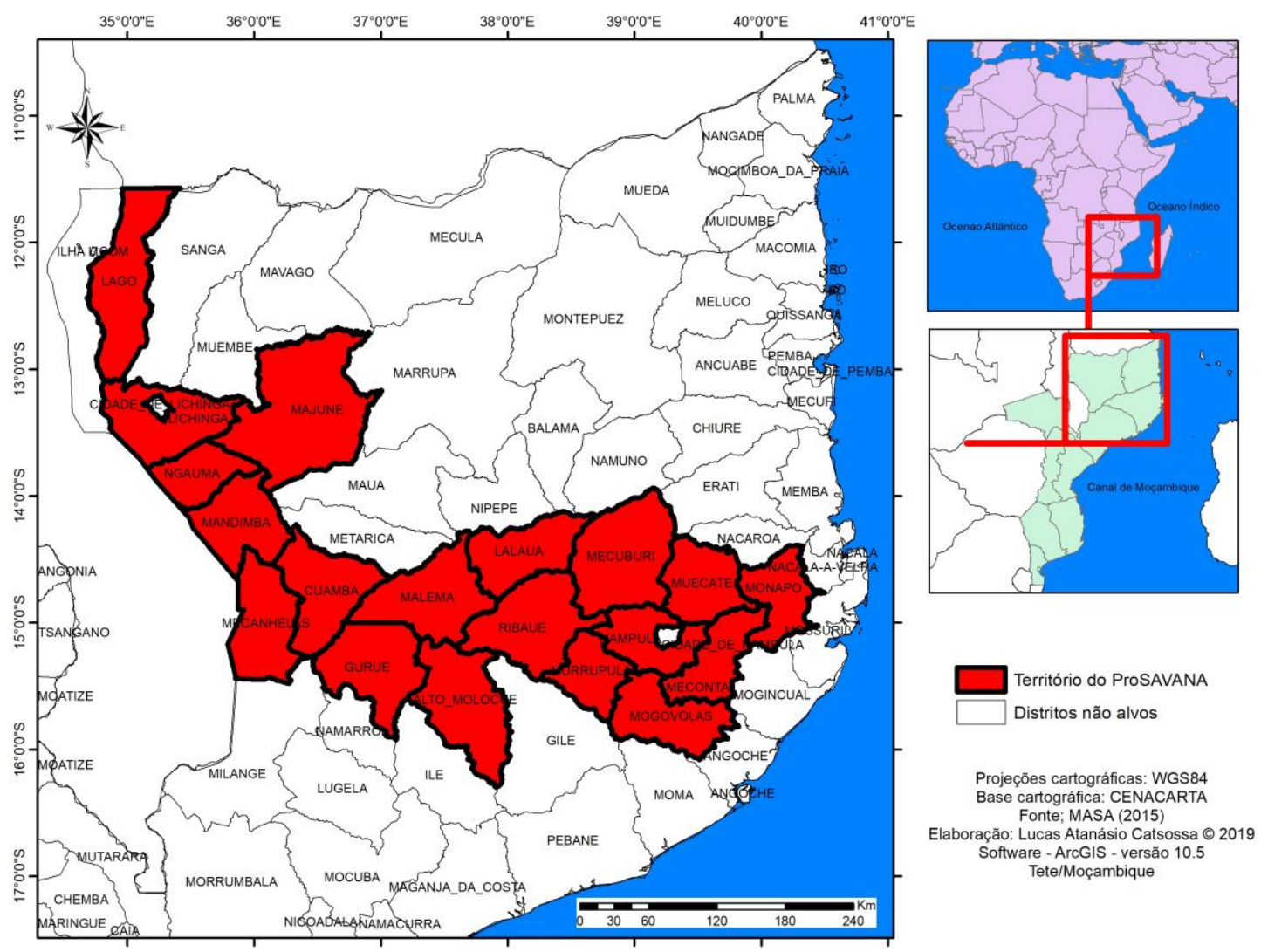

Este território é composta por 19 distritos e neles, vivem milhares de famílias camponesas fazendo uso diversificado dos seus territórios. As famílias que vivem neste território praticarem agricultura de subsistência, caracterizada pelo uso de enxada de cabo curto e pelo sistema de pousio dos solos. É importante realçar que, as famílias camponesas que se localizam nos distritos abrangidos pelo ProSAVANA, produzem seus alimentos com base nos seus conhecimentos e nos princípios agroecológicos. 
Figura 2. Família camponesa trabalhando a terra (a esquerda) e residência de uma família camponesa (a direita). Fonte: CATSOSSA, L. A, 2017 (Pesquisa de campo).

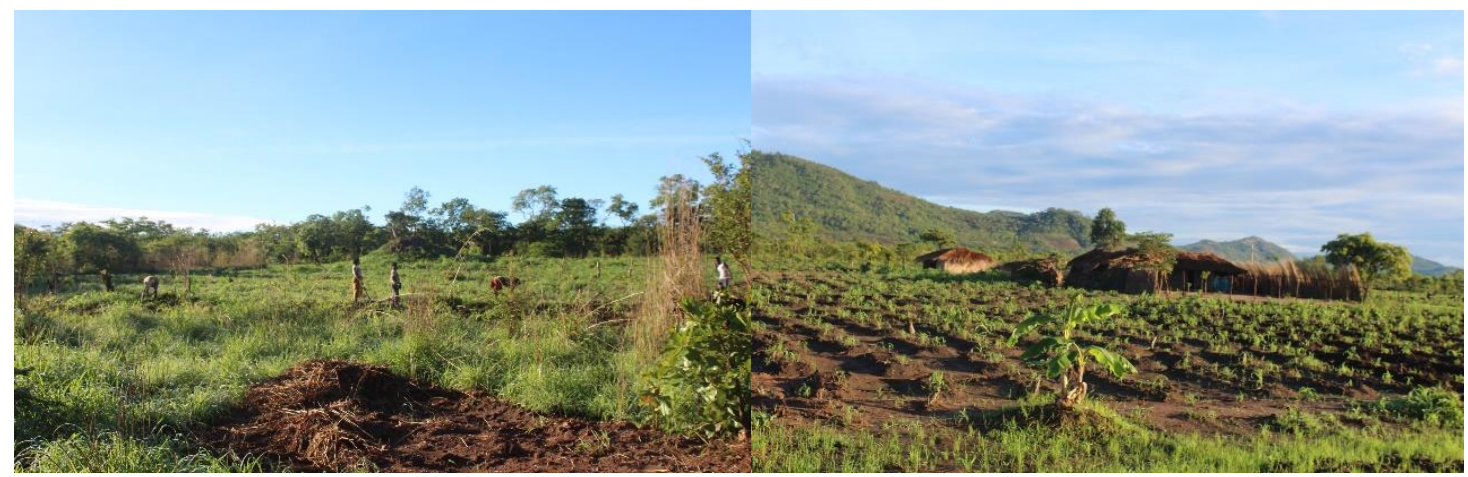

O acesso à terra pelas famílias camponesas é baseado nas normas e práticas costumeiras. Aqui, a herança da terra é, portanto, uma via de transferência não apenas da terra das gerações mais velhas para as gerações mais novas, mas também, do próprio modo de vida camponês. Neste caso, a terra acaba sendo um elo de ligação das gerações mais novas gerações com as antigas. Além disso, o acesso à terra é feita com base em boa-fé, o que significa que, basta uma pessoas singular e/ou coletiva viver 10 anos ou mais, automaticamente, o seu direito de uso é lhe assegurado e garantido pela Lei de Terras - Lei $n^{\circ}$. 19/97.

Igualmente, esta região é rica sob ponto de vista de diversidade cultural e étnico-linguístico. Os grupos étnicos-linguísticos predominantes nesta região são Macua's, na província de Nampula e Lomwés, na província da Zambézia, o que quer dizer que, obedecem uma certa organização social, sobretudo, baseada na linhagem familiar enquanto um processo de transferência do poder. Macaringue (2017) revela que nesta região, as famílias camponesas organizam-se também em pequenos agrupamentos de aldeias denominados nloko como também por um conjunto de agrupamento regulado, mas por causa da presença massiva do capital no Corredor de Nacala, estão em risco de desparecer. Este autor explica que:

O nloko é um território que geralmente é fundado por pessoas que estão ligadas por laços de familiaridade e o regulado através das imposições dos poderes formais. Essas duas estão sendo sufocadas pela organização instituída pelo governo que se desdobra em todos os sentidos para acabar com as formas locais de organização (MACARINGUE, 2017, p, 297 itálico do original).

Por sua vez, a comida destes povos está intrinsecamente ligado a cultura. Por exemplo, a mapira produzida localmente pelos camponeses, é usada em momentos cerimoniais pelos povos locais. Além da prática da agricultura, as famílias que vivem nos distritos afetados diretamente pelo ProSAVANA têm na pesca e caça como outras fontes de renda para o aumento das suas economias. Das florestas nativas, estas famílias retiram vários bens, como por exemplo, lenha para o uso doméstico, estacas para a cobertura das suas palhotinhas, madeira para a produção de utensílios domésticos, plantas medicinais e entre outros elementos naturais. 
Por sua vez, estas famílias por serem tradicionais, elas têm nestas florestas os seus espaços sagrados onde realizam as suas cerimônias tradicionais. É nestas florestas onde estão os "territórios da religiosidade", usados pelas famílias camponesas para realizar suas rezas. Por sua vez, é nestas florestas onde existem os cemitérios comunitários e até familiares. Os dados estatísticos em relação às famílias afetadas diretamente pelo ProSAVANA divergem. O governo moçambicano através do Plano Diretor do ProSAVANA versão zero, aponta cerca de 600.000 produtores familiares. Já as associações de camponeses e organizações da sociedade civil que militam no campo, avançam que o ProSAVANA afeta diretamente cerca de 800.000 produtores familiares (cf. CATSOSSA, 2017).

Embora tenham avançado para este número, as associações de camponeses e organizações da sociedade civil, alertam que, este número pode ser menor olhando para a forma abrangente do programa. Essa observação é legítima, partindo do pressuposto que pode ter havido mobilidade de pessoas de outros lugares não abrangidos para os distritos diretamente afetados pelo ProSAVANA. Por isso, em casos de implementação efetiva do ProSAVANA, deve-se fazer de novo um levantamento cauteloso e detalhado das pessoas que vivem nos distritos diretamente afetados por este programa. A particularidade dos distritos afetados diretamente pelo ProSAVANA, além de serem densos em termos populacionais, os mesmos apresentam boas condições agroecológicas caracterizadas pela fertilidade dos solos.

Essas características foram confirmadas durante a pesquisa de campo realizada em alguns dos distritos, no caso de Gurué e Alto-Molocué, na província da Zambézia, como também nos distritos de Malema, Ribáue, Meconta, Mecuburi, Monapo e Rapale, na província de Nampula. A maior dos distritos afetados diretamente pelo ProSAVANA, são considerados pelos próprios camponeses, associações de camponeses e organizações da sociedade civil como sendo celeiros, uma vez que a produção que daí sai, abastece-se com ela outros mercados nacionais.

Feita esta apresentação, resta apenas fazer uma análise mais apurada sobre este programas que diz ser a solução dos problemas sociais, sobretudo, a fome, a miséria e o desemprego no país. Além disso, destaca ainda que, em caso de implementação efetiva, irá aumentar os níveis de produção e produtividade do país. Estudos apontam que o uso do discurso produtivista e desenvolvimentista, faz parte do seu modus operandi, sobretudo, quando quer se territorializar num determinado lugar, mas que na verdade, quer empreender uma ocupação efetiva do territórios e por via disto, usá-lo para a acumulação ampliada do capital em escala global. Oliveira (2003) resume o agronegócio em duas palavras: “modernidade e barbárie”. Para Cubas (2018) elucida que:

Interpretar barbárie e modernidade, passa por compreender a centralidade do debate do capitalismo rentista e do uso (i)racional da terra. Isto é, a unidade indissociável entre latifúndio e agronegócio, entre a barbárie e modernidade, entre o arcaico e o novo, a partir da (ir)racionalidade rentista que 
exclui/expropria/marginaliza paradoxalmente os agricultores efetivos do lugar da (re)produção da vida, a terra (CUBAS, 2018, p. 224).

Já Fabrini e Ross (2014), desconstroem a imagem produtivista e desenvolvimentista do agronegócio que é apresentada a sociedade, destacando que, por de trás dela, existe algo escondido. Estes autores afirmam que "se de um lado, o agronegócio é sinônimo de produtividade, de outro, é excludente promotor da miséria, degradação ambiental, violências e tantas outras barbáries". Neste entendimento, no caso do ProSAVANA, estaríamos diante do neocolonialismo e/ou "imperialismo enquanto fase superior do capitalismo" (Lênin, 2012) global. É o neocolonialismo e/ou (sub)imperialismo porque os moçambicanos estão sendo apresentado apenas uma face do ProSAVANA, neste caso, a produtivista e desenvolvimentista, ocultando a outra, caracterizada pela ocupação das terras dos povos locais e, consequentemente, expulsão destes, a (super)exploração da força de trabalho, violência e entre outras barbáries.

Os autores mais criativos, sinalizam que a territorialização do ProSAVANA na savana moçambicana, evidencia práticas neoagrocolonialistas, isto é, neoagrocolonialismo (cf. MATOS, OLIVEIRA \& BARBOSA JR., 2018). A justificativa é que, o ProSAVANA se enquadra no atual quadro da corrida por terras agrícolas na África pelas potências imperialistas, no qual, o Brasil faz parte. Lembrar que Clements e Fernandes (2013), já avançavam que através do ProSAVANA, o Brasil estava a promover a grilagem internacional de terras em Moçambique da mesma forma que faz nos países latino-americanos, sobretudo, o Paraguai. Uma afirmação igual, é feita por Melo, Oliveira e Barbosa Jr., (2018), aonde duma forma incisiva afirma que através do ProSAVANA:

[...] o Brasil que tem a sua economia fortemente ancorada em commodities de origem mineral e agrícola, acaba, transpondo para aquele país as contradições internas que têm acarretado uma série de conflitos relacionados à apropriação e ao controlo da terra, da água e do subsolo (MELO, OLIVEIRA \& BARBOSA JR, 2016, p. 108).

Quando noutros momentos afirmamos que o ProSAVANA, era um "novo" programa brasileiro em Moçambique, mas que a (sua) sopa era aquela de sempre (cf. Catsossa, 2018), nos referíamos, portanto, as fortes cores coloniais que ele apresenta. As palavras "modernidade" e "colonialidade", embora estejam em páginas diferentes no dicionário da língua portuguesa, no caso em análise, são processos gêmeos, pois eles sempre estão juntos, na medida em que onde ocorre um, o outro está também presente e vice-versa. A "modernidade" se dá pela "colonialidade" assim como a "colonialidade" pela "modernidade" e ambas, são a face da mesma maldição no campo. Apropriadamente, Haesbeart e Porto-Gonçalves (2006, p. 19) elucidam que "o mundo moderno não é compreensível sem a colonialidade [...], vivemos um sistema-mundo modernocolonial, e não simplesmente, um mundo moderno". 
A "modernidade" se dá pela incorporação de algo "novo" e/ou do "moderno" num determinado território. Este processo, implica que as relações sociais e produtivas do território sejam "modernizadas", padronizadas e ordenadas de acordo com os interesses do modelo dominante. O ProSAVANA, representa a tal "modernidade" e "colonialidades", pois este programa visa instituir uma nova forma de organização social e produtiva dos territórios em Moçambique. O discurso oficial, sempre enfatizou que em Moçambique o ProSAVANA visa melhorar e modernizar a agricultura com vista o aumento da produção e da produtividade e que, a partir disso, acabaria com a fome e a miséria.

Os executores deste programa, apareceram com uma falta ideia de que, haveria a diversificação das culturas, entre elas, alimentares e comerciais (commodities). Dito de outras formas, haveria uma coexistência pacífica entre a agricultura camponesa e o agronegócio no mesmo lugar. Para eles, a coexistência pacífica, dar-se-ia pelo uso de Princípios de Investimentos Agrários Responsáveis (PIAR), em como se o capital fosse responsável no campo. Desta forma, o ProSAVANA seria diferente do PRODECER.

Aqui, existem aspectos que merecem uma análise mais atenta, pois este processo, está sujeito a várias contradições. Essas contradições são visíveis no Brasil, o mesmo país que diz pretender melhorar e modernizar a agricultura moçambicana. Primeiro, instituir uma nova organização social e produtiva num território onde existem povos que vivem com base no seu modo de vida, é, em si, um ato colonizatório. Com isso, pretendese dizer que, o modo de vida dos povos locais está sendo inferiorizado e ao mesmo tempo, considerado como arcaico pelos executores do ProSAVANA.

No entanto, não é verdade que o modo de vida que os camponeses locais têm levado é arcaico, mas sim, esta é uma justificativa para o imperialismo brasileiro e japonês avançar, já que se uniram no processo de ocupação do Corredor de Nacala para a implementação do ProSAVANA. A modernização como foi referenciado anteriormente, os territórios passa por introduzir novos usos do território, o que significa que, as antigas relações sociais, são destruídas durante o processo. É por isso que Fernandes $(2008$, p. 49) alerta que cada vez que "o agronegócio se territorializa com maior rapidez, [ao mesmo tempo], desterritorializa a agricultura camponesa" e com ela, todo o modo de vida camponês.

Por onde este modelo agrário/agrícola que se propõe para a modernização da savana moçambicana, torna-se quase impossível assegurar que este processo contraditório não ocorra. É por esta razão que a ideia de que será possível controlar por meio de Princípios Investimentos Agrários Responsáveis (PIAR), é apenas um mito. É uma forma que os executores do ProSAVANA viram para contornar as críticas dos camponeses, das organizações sociedade civil, acadêmicos e entre outros segmentos sociais atentos as contradições do desenvolvimento capitalista na agricultura. A realidade têm revelado que o capital é irresponsável, pois a racionalidade é pautada pelo lucro. 
Numa situação em que a luta acumulação ampliada do capital está cada vez maior no campo, os PIAR torna-se ineficiente em termos socioambientais, na medida que ninguém os segue no processo produtivo e isto faz com que não haja coexistência pacífica entre os modelos agrários. Para garantir maiores lucros, o agronegócio faz tudo para desterritorializa o campesinato, tomando as terras dos camponeses e consequentemente, expulsando-os para as cidades aonde tornam-se trabalhadores assalariados passíveis de serem explorados para a reprodução ampliada do capital, às vezes, tem sido o mesmo que lhes expropriou e Ihes expulsou dos campo. Essa forma de territorialização do agronegócio no campo, é considerada por Oliveira (2004) como sendo a "territorialização do capital monopolista na agricultura".

Em alguns casos, ao se territorializar, o capital apenas sujeita/subalterna os camponeses a lógica de produção do mercado, transformando-os em trabalhadores a seu serviço, na medida em que passam a produzir mercadorias agrícolas para exportação. Esta tem sido outra forma de destruição dos camponeses, mesmo sem ele se implantar diretamente. A isto, Oliveira (2004) chamou de "monopolização do território pelo capital monopolista". Isto para dizer que, ao se territorializar, o agronegócio cria todas as condições para a sua reprodução ampliada em escala global, mesmo que isto significa a destruição das práticas e/ou relações sociais preexistentes.

No caso moçambicano, o ProSAVANA apresenta estas duas faces em termos de territorialização. A primeira via, tudo indica, em caso de se avançar com a sua implementação efetiva, dar-se-á pela expansão direta das commodities nas savanas. Já existem, portanto, alertas segundo as quais, há riscos que podem levar a expulsão dos camponeses para outras áreas e, posteriormente, reassentamentos populacionais. Já a segunda via, dar-se-á pela expansão indireta das commodities nas savanas, o que significa que, haverá sujeição/subordinação dos camponeses a lógica produtiva do agronegócio.

Neste caso específico, a agricultura de contrato seria a via a ser usada pelos executores do ProSAVANA. Ambas as formas de territorialização têm impactos negativos na reprodução social do campesinato. No entanto, é incoerente pensar na diversificação de culturas num contexto de introdução de commodities. É incoerente porque ao se territorializar, o capital procura eliminar quem de fato é responsável pela diversificação das culturas no processo produtivo, na medida em que cria condições para que a produção agrária/agrícola seja de acordo com a sua racionalidade produtiva que passa pela expansão de monoculturas agroexportadoras no campo.

No entanto, no caso do ProSAVANA, existe uma maior possibilidade dos saberes e valores que atualmente guiam o modo de vida dos camponeses, serem destruídos caso este programa se efetive enquanto modelo agrário/agrícola dominante. A própria diversidade da produção camponesa, também está num risco eminente em caso de implementação efetiva do ProSAVANA. Tratando-se do agronegócio, os riscos disto 
acontecer são maiores, pois a experiência brasileira, não é promissora no que tange a convivência pacífica entre modelos de desenvolvimento agrário no campo.

Isso para dizer que, as autoridades brasileiras no caso do ProSAVANA, não estão sendo realista, sobretudo, por ocultar as contradições por de traz da modernização agrícola que são visíveis no seu próprio país. Santos $(2014$, p. 220) faz saber que a partir do momento em que o capital se territorializa num determinado lugar, "o fracasso da pequena produção e a falência econômica do campesinato, atinge sua autoestima, já fragilizada pelo preconceito dos de fora", segundo o qual, é portador de vestígios do passado. No caso moçambicano, a territorialização do ProSAVANA, baseou-se no preconceito, segundo o qual, os camponeses não são eficientes e muito menos, são competitivos em termos econômicos, daí que devem ser transformados e orientados para a produção virada para o mercado.

Esta transformação dos camponeses será por meio da incorporação dos chamados "novos" pacotes tecnológicos nos processos produtivos. Para alcançar altos índices de produção e produtividade, os executores do ProSAVANA, encontraram duas fórmulas mágicas. A primeira, passa por acabar com as práticas preexistentes consideradas como rudimentares, sobretudo, com os saberes camponeses. Neste sentido, a elevação dos níveis de produção e produtividade será feita com base no uso destes pacotes tecnológicos, composto por sementes transgênicas (de diversas variedades) e agrotóxicos (diversos).

De realçar que, o agronegócio só é maior produção e produtividade quando se usa estes pacotes tecnológico nos processos produtivos. A segunda fórmula mágica encontrada pelos executores do ProSAVANA para garantir a elevação dos níveis de produção e produtividade, passa por eliminar o sistema de pousio e a sua substituição pelo uso permanente da terra e segundo o discurso dominante, será possível através do uso intensivo de tecnologia e do capital no processo produtivo. É desta forma que é pensada a modernização agrícola no Corredor de Nacala. Acontecendo isto, poderá haver muitas transformações sócio-espaciais ao longo do Corredor de Nacala e a estrutura agrária local, irá ser dominada pela concentração de terras e expansão de commodities.

Isso pode ser mais grave no contexto da soberania alimentar/territorial, como também sobre a segurança alimentar e nutricional dos povos locais. Rigorosamente falando, verifica-se uma "romantização" do ProSAVANA por parte dos seus executores, na medida em que era visto como a solução dos males sociais em Moçambique. O ProSAVANA, precisa ser analisado sob ótica da "acumulação por espoliação" cunhada por David Harvey, porque trata-se de programas que promovem a destruição de todas as relações não capitalistas de produção e com elas, o modo de vida tradicional que caracteriza os povos locais.

Por sua vez, promove a apropriação e pilhagem dos recursos naturais disponíveis no território, vitais para a sobrevivência dos povos locais. Ao ser analisado, o ProSAVANA precisa ser enquadrado no atual contexto da 
mundialização da agricultura capitalista, caracterizado pela globalização do agronegócio. Só assim, é que será possível compreender melhor as suas reais intensões ao se implantar em Moçambique, saindo do Brasil, como também as contradições que a partir dele podem se verificar ao longo do Corredor de Nacala. O ProSAVANA não é um programa qualquer, ele tem uma dimensão geopolítica, e nele estão imbricados os interesses geopolíticos catalisados pela crise de preços de alimentos que assolou o mundo nos anos de 2007 e 2008.

O ProSAVANA é nada mais, nada menos que uma estratégia capitalista bem reformulada pelo Brasil e Japão para a ocupação efetiva da savana moçambicana pelo capital monopolista. As promoções que ocorrem inicialmente no Brasil, no Japão e mais tarde em Moçambique, não foram feitas para os camponeses, mas sim, para o setor privado. 0 Seminário Internacional realizado em 2011, em São Paulo, subordinado ao título «Agronegócio em Moçambique: Cooperação Internacional Brasil-Japão e Oportunidades de Investimenton, é revelador que o ProSAVANA é a expressão exata da atual geopolítica da questão agrária mundial conforme ilustra a tabela 2.

Tabela 2. Promoção do ProSAVANA no Brasil. Fonte: Catsossa (2017).

\begin{tabular}{|c|c|c|}
\hline Temas & Orador/a & Cargo/função \\
\hline & Maco Ferani & Diretor da $A B C$ \\
\hline Cooperação como promotora e & Kenzo Oshima & Vice-Presidente da JICA \\
\hline oportunidade de investimento & $\begin{array}{l}\text { Murade Muragy } \\
\text { Pedro Arraes }\end{array}$ & $\begin{array}{c}\text { Embaixador de Moçambique no Brasil } \\
\text { Presidente da EMBRAPA }\end{array}$ \\
\hline & Wagner Rossi & Ministro da Agricultura no Brasil \\
\hline & José Pacheco & $\begin{array}{c}\text { Ministro da Agricultura de } \\
\text { Moçambique }\end{array}$ \\
\hline \multirow[t]{2}{*}{$\begin{array}{l}\text { Agronegócio em Moçambique: } \\
\text { potencial e macro-institucional }\end{array}$} & Kátia de Abreu & $\begin{array}{c}\text { Senadora e Presidente da CNA } \\
\text { (Confederação Nacional da Agricultura } \\
\text { e Pecuária) }\end{array}$ \\
\hline & Roberto Rodrigues & $\begin{array}{l}\text { Presidente do Conselho Superior do } \\
\text { Agronegócio (FIESP) }\end{array}$ \\
\hline \multirow[t]{2}{*}{$\begin{array}{c}\text { Desenvolvimento do agronegócio } \\
\text { brasileiro }\end{array}$} & Aysson Paulinelli & Ex-ministro da Agricultura do Brasil \\
\hline & JICA \& ABC & $\begin{array}{l}\text { Representante do governo japonês e } \\
\text { brasileiro no processo de }\end{array}$ \\
\hline $\begin{array}{c}\text { Panorama do Programa Triangular } \\
\text { para o Desenvolvimento das Savanas }\end{array}$ & & $\begin{array}{l}\text { implementação do ProSAVANA } \\
\text { Coordenação do ProSAVANA na }\end{array}$ \\
\hline $\begin{array}{c}\text { Tropicais de Moçambique } \\
\text { (ProSAVANA) }\end{array}$ & Alberto Santana & $\begin{array}{c}\text { EMBRAPA: Projeto I-Pesquisa e } \\
\text { Transferência de Tecnologia Agrícola } \\
\text { em Moçambique }\end{array}$ \\
\hline Como investir em Moçambique? & CIP (Centro de Promoção de & \\
\hline Localização, desafios e incentivos & Investimento) & Governo de Moçambique \\
\hline $\begin{array}{l}\text { Atuação de instituições de crédito no } \\
\text { apoio ao desenvolvimento da } \\
\text { agricultura em Moçambique }\end{array}$ & $\begin{array}{l}\text { Thierry Tanoh } \\
\text { BNDES }\end{array}$ & $\begin{array}{c}\text { Vice-presidente da África, América } \\
\text { Latina e Carribe-International Financial } \\
\text { Corporation IFC-Banco Mundial } \\
\text { Governo do Brasil }\end{array}$ \\
\hline \multicolumn{3}{|l|}{ Moçambique } \\
\hline Agronegócio em Moçambique - a & & \\
\hline $\begin{array}{l}\text { experiência da Miranda Agroindústria } \\
\text { Investimento Japonês }\end{array}$ & $\begin{array}{l}\text { António Miranda } \\
\text { Mitsubishi Co }\end{array}$ & $\begin{array}{c}\text { Representante da empresa } \\
\text { Representante(s) da empresa vindo do } \\
\text { Japão e Brasil }\end{array}$ \\
\hline
\end{tabular}


Como se pode ver na tabela 2, nenhuma organização camponesa esteve presente em representação dos camponeses e isto, apenas reforça a tese de que este programa não foi concebido pensando no campesinato moçambicano. Em outras palavras, reforça a tese segundo a qual, este programa é anticampesinista e pró-capital. A ocupação do Corredor de Nacala pelo ProSAVANA, revela que se está diante dos ajustes espaço-temporais nos territórios de existência camponesa, visando garantir acumulação privada do capital em escala global e há motivos suficientes para fazer tais afirmações. O processo de ocupação do Corredor de Nacala pelo ProSAVANA, não difere do que aconteceu no cerrado brasileiro com a implantação do PROCECER.

A forma como o território que alberga o ProSAVANA foi recortado, apenas revela a intensão do capital em poder se reproduzir primitivamente a escala global. O ProSAVANA apresenta a mesma filosofia do PRODECER, pois as culturas que serão usadas para a modernização agrícola do Corredor de Nacala são quase as mesmas, entre elas, a soja, o milho, a cana-de-açúcar e algodão. A duração do ProSAVANA no Corredor de Nacala é também a mesma que o PRODECER teve no cerrado brasileiro, que é de 20 anos. Enquanto, o PRODECER foi dividido em «PRODECER I», «PRODECER I|» e «PRODECER II|», a divisão do ProSAVANA foi feita por períodos, entre eles: «Período de início», «Período de crescimento» e «Período de amadurecimento».

O discurso produtivista e desenvolvimentista que permeou a elaboração e implementação do PRODECER no cerrado brasileiro, manteve-se intacto no ProSAVANA. As características do PRODECER, estão presente no ProSAVANA, fato que revela estar em curso uma "replicação" do primeiro programa em Moçambique. A experiência do cerrado brasileiro parece estar a repetir-se em pleno século XXI e desta vez em Moçambique, pois durante a implementação do PRODECER no século XX, a ferrovia da Vale por onde transportava o minério de ferro no nordeste foi também utilizada para o escoamento de commodities agrícolas para o porto de São Luís, de onde eram exportadas para outros mercados via marítima.

No caso moçambicano, a ferrovia pertence à mineradora brasileira Vale Moçambique (ex-Vale do Rio Doce), onde transporta o carvão mineral que é exportado na via de Moatize, na província central de Tete. Essa ferrovia começa na vila de Moatize, passando por Malawi e vai desaguar no distrito de Nacala Porto onde as commodities são exportadas via marítima para o mercado internacional. Com a entrada do ProSAVANA, essa ferrovia foi revitalizada, ou seja, ampliada como forma de aumentar a sua capacidade em termos de carga. De realçar que, a ampliação desta ferrovia levou a expropriação e expulsão de centenas de famílias camponesas das suas terras.

A JICA (Agência Japonesa de Cooperação Internacional) é que esteve por detrás da revitalização desta ferrovia (FUNADA-CLASSEN, 2013). Como se vê, há uma articulação entre os interesses da Vale e do ProSAVANA no Corredor de Nacala. Em termos geopolíticos e geoestratégicos, o Corredor de Nacala está bem 
localizado e, é por causa disto mesmo que, tem sido alvo do capital nos últimos anos. Não foi por acaso também que o ProSAVANA se implantou exatamente neste território, pois as condições em termos logísticos já tinham sido minimamente criadas.

Neste sentido, está criada toda a base material para acumulação ampliada do capital, pois implantandose neste território, existem todas as condições em termos logísticos para o sucesso do ProSAVANA, uma vez que os produtos seriam escoados diretamente para o porto de Nacala e daí, para o mercado asiático e para Japão, em particular usando o mar. Ideologicamente, ambos os programas (PRODECER e ProSAVANA) tem traços (e/ou são fruto) da chamada Revolução Verde, que de verde não teve, se não, o seu lado vermelho caracterizado pela pilhagem territorial e com ele, os recursos naturas vitais para a sobrevivência das comunidades tradicionais, expropriação e expulsão dos camponeses dos seus territórios, destruição da biodiversidade, contaminação dos recursos hídricos, dos sujeitos e entre outras barbáries.

Não constitui uma verdade absoluta que o ProSAVANA será a solução do problema da fome em Moçambique, pois a sua racionalidade não é a de produzir alimentos que vão diretamente à mesa das famílias moçambicana, mas sim, é pela produção de commodities agrícolas para a exportação, a sua base de acumulação. Quem produz comida que vai diretamente à mesa dos cidadãos não é o agronegócio, mas sim, agricultura camponesa, mas é esta que está para ser "exterminada", na medida em que se pretender integrar os camponeses a lógica do mercado, produzindo mercadorias agrícolas em vez de culturas alimentares.

O PRODECER, programa o qual o ProSAVANA se inspira, gerou várias contradições durante e após a sua implementação no contexto da segurança alimentar. Schlesinger (2013, p. 45) fazendo uma avaliação deste programa afirma que, o "PRODECER apresentado como uma verdadeira revolução a favor da produção de alimentos, [...] resultou em insegurança alimentar e necessidade de compra de alimentos de outras regiões". Essa necessidade de compra dos produtos caso ocorra a implementação efetiva do ProSAVANA no Corredor de Nacala, não pode ser ignorada.

Já que a intensão do ProSAVANA é transformar os camponeses locais em produtores competitivos integrados ao mercado por via da subcontratação, a situação pode ser pior ainda, na medida em que estes, perderão o foco produzindo mercadorias em vez de alimentos que vão diretamente a sua mesa. As culturas em implementação, na sua maioria não são de consumo direto. Trata-se de culturas como a soja, milho, canade-açúcar, algodão, gergelim e entre outras. Localmente, os camponeses consomem milho, feijões diversos (nhemba, manteiga, boer), mapira, mexoeira, mandioca, batata-doce, abóbora, quiabo, e entre outras culturas.

Por sua vez, as sementes que estão para ser introduzidas no Corredor de Nacala, são em si, uma ameaça à soberania alimentar, pois trata-se de sementes laboratoriais (transgênicas). Como se sabe, a soberania 
alimentar e a segurança alimentar, são irmãs gêmeas, ao se afetar a primeira, a segunda fica afetada também. Ao introduzir sementes cuja função é garantir a reprodução ampliada do capital e não para o consumo direto das pessoas, torna-se uma ameaçada a segurança alimentar e nutricional dos povos locais. O mais grave ainda, é que o milho que está para ser introduzido, apenas serve para a produção de ração animal para alimentar galinhas (frangos). Schlesinger (2013) afirma que esse tipo de milho não é saboroso e isto foi possível de comprovar no Brasil durante a pesquisa de campo em 2015.

Como se pode ver, nota-se uma tentativa de substituição do que se come diretamente pelo que não se come diretamente. As alertas sobre a possibilidade de reprodução da insegurança alimentar em Moçambique, vêm ainda do Brasil e desta vez, por meio de Inocêncio (2016), depois de Clements e Fernandes (2013) e Catsossa (2017) terem chamado atenção sobre este a possível ocorrência deste fenômeno por causa do modelo agrário proposto. Em seu texto «Brasil/Japão: Cooperação para o desenvolvimento dos cerrados ou estratégia capitalista para a ocupação de produção capitalista das savanas? " Inocêncio (2016) afirma que:

No Brasil a soja foi o principal cultivar introduzido e abriu novos territórios a exploração capitalista. Em Moçambique, há cultivo de outros gêneros alimentícios, alguns relacionados aos hábitos alimentícios moçambicanos, porém a abertura de novas áreas agrícolas em nada contribui para a solução da fome no continente (INOCÊNCIO, 2016, s/d).

Além de estar em situação de alerta, as organizações camponesas estão cientes que o ProSAVANA não vai garantir a sua soberania alimentar e muito menos, a segurança alimentar e nutricional no país. Por exemplo, a liderança da Associação Rural de Ajuda Mútua (ORAM) assegura que:

Dentro do ProSAVANA, não há espaço para falar da segurança alimentar. As pessoas não vão comer milho, não vão comer soja. As pessoas precisam manter aquelas culturas básicas, o quiabo, o tomate, o alface o milho para a sua própria alimentação, a abóbora, a melancia, onde está o espaço disto dentro do plano diretor do ProSAVANA? ${ }^{1}$

Também não é verdade que o ProSAVANA vai melhorar a vida das famílias camponesas ao longo do Corredor de Nacala, pois no agronegócio a concentração de terras e de renda é maior. Socialmente, o agronegócio é excludente e promotor do desenvolvimento desigual por onde se territorializa e foi o que aconteceu no cerrado brasileiro durante a implementação do PRODECER (Pessôa, 2015; Clements \& Fernandes, 2013; Santos, 2014) e tudo indica que o ProSAVANA no Corredor de Nacala, não será tão diferente.

A territorialização do agronegócio, leva a desterritorialização das práticas preexistentes, o que desemboca em fortes conflitos sociais, não apenas por terras, mas também por modelos agrários. Embora seja no contexto de outros programas, esse cenário é visível ao longo do Corredor de Nacala, território escolhido para a implementação do próprio ProSAVANA. É verdade que pode ter havido alguns reajustes do programa,

\footnotetext{
${ }^{1}$ Entrevista realizada em Janeiro de 2016, cidade de Nampula.
} 
tentando diferenciá-lo com a primeira versão, mas modelos de desenvolvimento agrários como o que o ProSAVANA propõe, as contradições são inevitáveis. Olhando para a proposta do ProSAVANA, tudo vai no sentido de que haverá alguma diferenciação social entre os camponeses caso seja implementado na sua plenitude, pois isso é inevitável por onde o agronegócio se territorializa.

Neste sentido, haverá alguns camponeses que serão ricos (e este grupo será composto por aqueles que poderão se integrar com sucesso), mas uma margem maior cairá na miséria e quiçá, pior do que estavam antes, tendo encontrado que alguns poderão perder seus territórios e outras fontes de sobrevivência. Não é verdade ainda que, o ProSAVANA será fonte de empregos, pois com o avanço tecnológico, o desemprego gerado pelo setor da agricultura tem aumentado em resultado do uso elevado de maquinaria. Neste processo, as pessoas são substituídas por máquinas agrícolas, cabendo elas, procurar empregos não agrícolas nas cidades. Outras pessoas depois de expropriadas, transformam-se em assalariados sazonais nas empresas agrícolas e, é o que é mais recorrente no agronegócio. Numa leitura minuciosa em torno do ProSAVANA, Jacinto (2014) faz as seguintes afirmações de possíveis contradições socioterritoriais:

A invasão da savana pelo agronegócio e pela soja é semelhante, na envergadura dos projetos e no tipo de ocupação que lhe está associada, às frentes pioneiras que invadiram o sertão brasileiro e o (des) mataram enquanto remetiam e outros sem terras. Este modelo de desenvolvimento, promovido quase sempre a partir do investimento estrangeiro, fomenta a monocultura, ocupa vastas áreas (14,5 milhões de hectares) e afeta muitas pessoas ([na altura] 4 milhões [de famílias camponesas]). O ProSAVANA, concebido a imagem e semelhança do PRODECER, Programa de Desenvolvimento dos Cerrados, irá produzir fundamentalmente, soja e gado para exportar para países ricos. Os camponeses terão o mesmo destino que tiveram em todo o lado: a troco duma indemnização sempre regateada e insuficiente e em nome duma modernidade duvidosa terão que abandonar as terras dos seus antepassados sem perceber como tamanha maldade lhes foi bater a sua porta (JACINTO, 2014, p. 94).

Na mesma perspectiva, Pessôa (2015) afirma que, se durante a implementação do PRODECER no cerrado brasileiro o:

[...] processo de produção e apropriação do espaço do Cerrado pelo capital, houve interesse em organizar e reorganizar esse espaço para atender o mercado internacional, no ProSAVANA não será diferente. [...]. A leitura feita sobre o ProSAVANA, a partir do PRODECER, deixa em aberto reflexões e questionamentos para que possamos pensar os verdadeiros interesses de cooperação internacional. Mesmo que em seus objetivos estejam citados a preocupação com a questão ambiental, com a segurança alimentar - três palavras-chaves fundamentais nessa discussão - soubemos que não é tarefa simples conciliar esse tripé no processo desenvolvimento capitalista no campo. Esse desafio é um ponto de partida para compreender as transformações no meio rural nos dois biomas destacados (PESSÔA, 2015, p. 453-456).

De fato, os desafios são vários para o caso moçambicano, sobretudo, para a compreensão das transformações que possam advir da implementação efetiva do ProSAVANA no Corredor de Nacala, tendo em conta que dentro deste bioma, além de existir uma rica e imensa biodiversidade, vivem milhares de famílias camponesas que depende unicamente das terras, as mesmas que estão na mira deste programa e dos recursos naturais aí disponíveis para a sua reprodução social. 


$$
\begin{array}{r}
\text { "Para que os oprimidos se unam entre si, é preciso que cortem o cordão umbilical, de caráter mágico e } \\
\text { mítico, através do qual se encontram ligados ao mundo da opressão». } \\
\text { Paulo Freire - Pedagogia do Oprimido } \\
\text { "Apesar da subordinação e conivência do executivo de Armando Guebuza face aos interesses } \\
\text { capitalistas do Japão, os moçambicanos reagiram fortemente e estão decididos a manter-se na } \\
\text { vanguarda popular para impedir o avanço do Programa ProSAVANA. O povo compreende o que está } \\
\text { em jogo e por que» } \\
\text { Jeremias Vunjanhe (2014). } \\
\text { "Não ao ProSAVANA! Sim à nossa agricultura camponesa e às nossas sementes nativas. Terra é tudo } \\
\text { que temos. Não aceitamos que nos retirem o nosso sustento e a nossa liberdade de produzirmos os } \\
\text { nossos alimentos». } \\
\text { Campanha Não ao ProSAVANA (2017). }
\end{array}
$$

\begin{abstract}
"Apesar da subordinação e conivência do executivo de Armando Guebuza face aos interesses capitalistas do Japão, os moçambicanos reagiram fortemente e estão decididos a manter-se na vanguarda popular para impedir o avanço do Programa ProSAVANA. O povo compreende o que está em jogo e por que» Jeremias Vunjanhe (2014)
\end{abstract}

Em Moçambique, a soberania popular é uma prerrogativa constitucional e a mesma, reside no povo. Neste sentido, em casos de ameaça, cabe a este mesmo povo lutar e resistir contra a dominação (neo)colonial. E porque o ProSAVANA tem fortes corres (neo)coloniais, o povo não se deixou intimidar pelas potências (sub)imperialistas (Brasil e Japão) e, mais uma vez, decidiu lutar e resistir contra as plantações (neo)coloniais em reintrodução no Corredor de Nacala pelo ProSAVANA. A entrada do ProSAVANA em Moçambique deparouse com fortes contestações populares, lideradas pelas associações de camponeses, organizações da sociedade civil.

Por considerarem nociva ao campesinato, as organizações da sociedade civil moçambicanas, formaram redes com os movimentos sociais estrangeiros, sobretudo, do Brasil e do Japão e isto visava "barrar" a implementação efetiva do ProSAVANA no Corredor de Nacala. Das organizações sociais brasileiras que tiveram um papel de revelo na consolidação das lutas e resistências contra o ProSAVANA em Moçambique, são as seguintes: Movimento dos Trabalhadores Rurais Sem-Terra (MST), Comissão Pastoral da Terra (CPT), Movimento dos Pequenos Agricultores (MPA) e FASE/Brasil. Só para citar alguns exemplos. Do lado japonês, o Centro de Voluntariado Internacional do Japão (JVC, em inglês) desempenhou um papel importante neste processo.

De realçar que, as organizações sociais brasileiras e japonesas, continuam presentes nas lutas e resistências contra a implementação efetiva do ProSAVANA em Moçambique, algumas vezes, pressionando os seus governos a desistir. A ocupação de grandes áreas de terras pelo capital para a produção de commodities agrícolas, é para as organizações da sociedade civil uma ameaça à soberania territorial e ao mesmo tempo, alimentar. Seria, portanto, a recolonização do país pelo agronegócio. Por sua vez, os 
camponeses se inseriram na dinâmica dos movimentos sociais, lutando e resistindo para que as suas terras não sejam tomadas e ocupadas pelo ProSAVANA.

Para os camponeses, a terra é mais que um instrumento de trabalho, pois sua relação com a terra é mítica, na medida em que os ligam aos seus ancestrais. Neste sentido, expropriar e expulsar um camponês da sua terra, simbolicamente, é o mesmo que matá-lo, pois a terra é o único nó e/ou cordão umbilical que lhe une aos seus antepassados. Por isso, quando os camponeses lutam e resistem contra a sua expropriação e expulsão do campo, estão ciente que essa relação mítica existem. Ao sair em defesa da sua terra, significa que, os camponeses querem manter os seus sabres e valores secularmente acumulados que, por sua vez, são transmitidos e/ou transferidos de geração em geração.

Como foi referenciado anteriormente, a herança tem sido um dos mecanismos, não só de transferência de poder, mas também de terras e, com eles, todos os saberes e valores tradicionais. Neste sentido, a sua luta e resistência contra o ProSAVANA, é para a manutenção do seu modo de vida tradicional, embora contestem também o agronegócio enquanto modelo agrário/agrícola dominante. As contestações do ProSAVANA pelos camponeses, foi evidente durante a "IIII Conferência dos Povos, subordinado ao tema "Entre os modelos dominantes de desenvolvimento agrário as alternativas populares», realizado em Outubro de 2017, na cidade de Maputo.

Figura 3. Mulheres camponesas protestando a implementação efetiva do ProSAVANA. Fonte: CATSOSSA, L. A, 2017 (Pesquisa de campo).

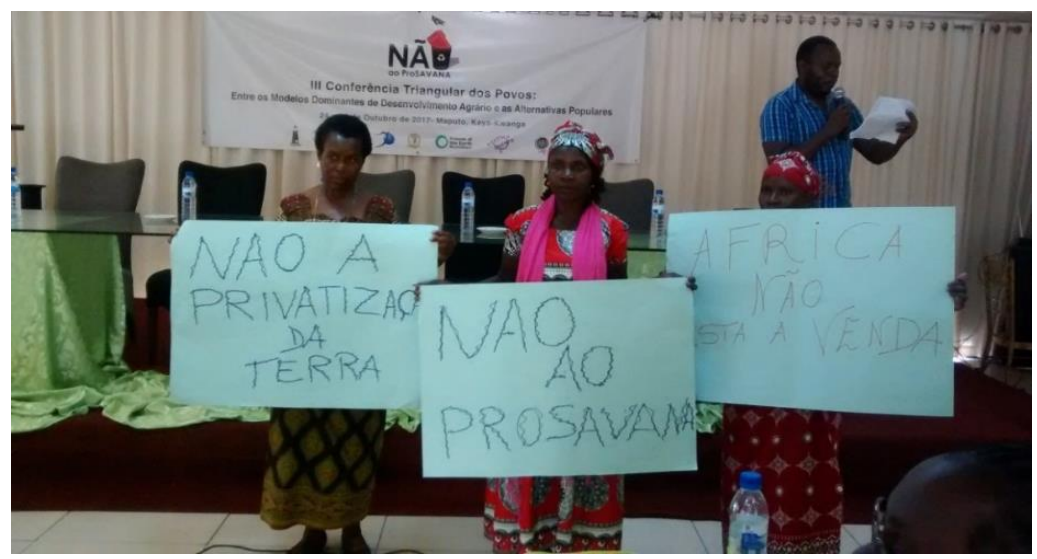

Nas mãos das três mulheres que aparecem na figura 3, algo chama atenção. Cada uma exibe um cartaz contendo uma mensagem de repúdio a este programa e é possível visualizar os seguintes dizeres: “Não a privatização da terra", "Não ao ProSAVANA" e "África não está à venda". Na primeira mensagem, fica a ideia de que essas mulheres estão cientes de a terra é o único instrumento de trabalho e meio de sobrevivência. 
Estas mulheres camponesas, estão cientes também que a privatização da terra pode inibir-lhes o usufruto dos recursos naturais aí existentes. Na segunda mensagem, elas sabem que além de ser antidemocrático, o agronegócio é uma ameaça para o seu modo de vida no campo.

Nesse sentido, para os camponeses, lutar e resistir contra o ProSAVANA é uma questão de vida. Em outras palavras, aceitar que a implementação deste programa se efetive em seus territórios nos moldes que foi concebido, significa chancelar a sua morte simbólica. Finalmente, a terceira mensagem denunciam o atual neocolonialismo onde se tem usado discursos desenvolvimentistas, enquanto por detrás disso, existem interesses obscuros. Essas mulheres estão cientes de que as suas terras na África e Moçambique em particular, podem estar entregues pelos governos nacionais as corporações capitalistas para acumulação privada da riqueza.

A gênese das contestações camponesas lideradas por associações de camponeses e organizações da sociedade civil está relacionada com vários fatores, entre eles, o atropelo a legislação nacional como também internacional. A forma não transparente de como o ProSAVANA foi "arquitetado" pelos seus mentores (neste caso Brasil e Japão), está também na origem das contestações que este programa tem vindo a sofrer desde que foi tornado público em Moçambique. A União Nacional de Camponeses (UNAC), um dos maiores movimentos campesinos do país de expressão nacional e internacional foi a primeira organização a denunciar a falta de transparência no processo de implementação do ProSAVANA. Num pronunciamento realizado na cidade de Nampula, em Novembro de 2012, a UNAC descrevia o seguinte cenário:

Desde que ouvimos falar do Programa ProSAVANA, temos notado uma insuficiência de informação e reduzida transparência por parte dos principais atores envolvidos (Governos de Moçambique, Brasil e Japão). Nós camponesas e camponeses, condenamos a forma como foi elaborado e se pensa implementar o ProSAVANA em Moçambique, caracterizado pela reduzida transparência e exclusão das organizações da sociedade civil em todo processo, em particular as organizações de camponeses (UNAC, 2012, p. 1).

Os camponeses diretamente afetados pelo ProSAVANA não foram convocados para participar na sua elaboração. É verdade que não poderiam ser todos os camponeses, mas os seus representantes, estes sim, poderiam dar opinião sobre o modelo de produção que estava sendo implantado e quiçá, deixar as demandas dos camponeses moçambicanos e, sobretudo, do Corredor de Nacala. É direito das comunidades serem consultadas sempre que o grande investimento se territorializa nas zonas rurais para evitar-se possíveis sobreposição de usos e conflitos sociais e a Lei de terras em vigor no país - Lei no. 19/97 é clara nisso.

Esta lei obriga qualquer investidor, seja ele nacional como estrangeiro, a realizar prévia "consulta às comunidades, para efeitos de confirmação de que a área está livre e não têm ocupantes"”. Eis, que o governo

\footnotetext{
${ }^{2}$ Cf. Artigo 13, número 3.
} 
entregou as terras comunitárias ao capital nipo-brasileiro para se reproduzir no Corredor de Nacala, ignorando a legislação de terras aprovada pelo próprio Estado, situação que desembocou em tensões de territorialidades no campo. Essas tensões de territorialidades resultam pelo fato do governo moçambicano junto dos seus parceiros de cooperação não ter feito consultas comunitárias prévias, já que a legislação prevê isso.

Para fraudar as consultas comunitárias, o governo moçambicano usou a ideia enganosa segundo a qual em Moçambique tinha terras "livres" e "subutilizadas" ao longo do Corredor de Nacala, as quais poderiam ser ocupadas pelo ProSAVANA. As terras que eram classificadas como sendo "livres" e "subutilizadas" eram aquelas que os camponeses deixam em pousio por um determinado período enquanto utilizam outras unidades produtivas para poder recompor-se. Quando o ProSAVANA começou a avançar com as suas atividades, este viu-se mais tarde a ser contestado pelos camponeses locais.

Um dos militantes da Associação Rural de Ajuda Mútua (ORAM), uma associação camponesas que atua no campo moçambicano, rebatendo a ideia falaciosa de que havia muitas terras em desuso, reagiu destacando que "se reparares o Corredor de Nacala, pode fazer essa viagem e acredito que vai fazer daqui a Nacala, não vai conseguir fazer 5, 6 ou mais quilómetros sem encontrar lá um grupo de pessoas que está a habitar ${ }^{3 \prime \prime}$. A União Nacional de Camponeses (UNAC), rebate também, afirmando que:

Se fores agora a Cuamba passar por este corredor até a cidade de Nacala, aqui no meio aqui não vais apanhar espaço pelo menos de $10 \mathrm{~km}$ desocupado. Se não tem casa, tem machamba e se não tem machamba, tem algumas árvores que são cajueiros ${ }^{4}$.

Percorridos alguns distritos diretamente afetados pelo ProSAVANA, foi possível constatar que, não havia tanta terra como o governo, o que sugere afirmar que os cálculos feitos não são realistas. Quanto mais ignoradas fossem pelos executores do ProSAVANA, as organizações da sociedade civil, ampliavam as suas ações de lutas e resistências contra este programa, numa clara luta de classes.

Tratava-se, portanto, de uma disputa paradigmática por modelos agrários/agrícolas, onde os primeiros privilegiavam o agronegócio e os segundos, um modelo alternativo, neste caso, agricultura camponesa por ser socialmente inclusivo e ambientalmente sustentável. As consultas comunitárias, diga-se de passagem, foram realizadas a ferro e fogo, ou seja, por força maior das organizações da sociedade civil e associações de camponeses depois de várias tentativas dos executores do ProSAVANA avançar com a implementação autoritária. A liderança da ORAM descreve que:

Em relação as consultas públicas, sinto que todos os processos devem ser participativos e devem decorrer antes que haja implementação de um determinado programa. Se reparar muito bem, a questão do ProSAVANA, são vários programas dentro dele, tem várias fases, a fase de divulgação,

\footnotetext{
${ }^{3}$ Entrevista realizada em Janeiro de 2016, na cidade de Nampula.

${ }^{4}$ Entrevista realizada em Janeiro de 2016 , na cidade de Nampula.
} 
projetos de impacto rápido que já vem sendo implementados. Então, não deveria ter começado antes que acontecesse esse processo de consultas públicas ${ }^{5}$.

As consultas comunitárias, diga-se de passagem, foram para o inglês ver. Além de terem sido excludentes, não abrangentes e de ter havido falta de transparência durante as consultas comunitárias, aqueles que tinham uma opinião contrária da classe dominante, isto é, dos executores do ProSAVANA, eram intimidados e "quando necessário, repressão contra as reivindicações das comunidades e coerção psicológica contra os críticos do programa" (MOSCA \& BRUNA, 2015, p. 9). A intimidação, violência psicológica e agressão dos que criticavam o ProSAVANA, foram outros aspectos que se verificaram no processo de implementação do ProSAVANA.

No caso da agressão, verificou-se na cidade de Nampula, durante um encontro organizado pela MAJOL, uma empresa de consultoria contratada pela JICA (Agência Japonesa de Cooperação Internacional) que supostamente tinha objetivo de ouvir (e/ou auscultar) as demandas das organizações da sociedade civil. Desconstruídas as teses da MAJOL sobre o ProSAVANA, esta, avançou com agressão verbal e por pouco, o encontro se tornaria no ato de demonstração de força. Os militantes da União Nacional de Camponeses (UNAC), é que foram vítimas das ações violentas da MAJOL. Os ativistas vítimas da ação perversa da MAJOL, destacaram que, esta instituição, não queria auscultar ninguém, mas sim, identificar as pessoas mais radicais nas organizações da sociedade civil e depois avançar com o processo de cooptação das mesmas.

Mais tarde, verificou-se a divisão das organizações da sociedade civil em dois grupos diferentes que defende também interesses distintos. Catsossa (2017) classificou o primeiro grupo de "ala anti ProSAVANA» e o segundo de "ala pro-ProSAVANA». O primeiro grupo tem suas sedes na capital moçambicana, cidade de Maputo enquanto que no caso do segundo, estão dentro do Corredor de Nacala, área de incidência direta do ProSAVANA. Essa estratégia da MAJOL pode ser vista no sentido de dividir para reinar. Pelo fato do primeiro grupo ser o mais radical nas suas visões nos seus pronunciamentos sobre o ProSAVANA, este foi sendo marginalizado no que tange ao acesso a informação sobre o programa pelos seus executores, beneficiando os segundos, já que estes eram moderados nas suas opiniões.

Mais tarde, o primeiro grupo, acusou o segundo de ter recebido valores avultados de dinheiro com os executores do ProSAVANA, sobretudo, da contraparte japonesa por meio da JICA para avançar com o projeto de desinformação dos camponeses, fazendo-os acreditar que este programa vinha para ajudá-los a progredir na sua vida. A divisão das organizações da sociedade civil, fez com que o movimento anticapitalista que lutava inicialmente contra o ProSAVANA se fragilizasse, pois o número de militantes terá diminuído. Contundo, o ProSAVANA ficará pela história do país como o programa que, mais dividiu as organizações da sociedade civil

\footnotetext{
${ }^{5}$ Entrevista realizada em Janeiro de 2016, na cidade de Nampula.
} 
que se dizem defender e proteger os interesses e direitos das comunidades rurais e dos camponeses, em particular.

O ProSAVANA veio revelar também as lutas de classes dentro das organizações da sociedade civil, onde certos grupos usando o nome das comunidades rurais e dos camponeses em particular, procuravam extrair as chamadas mais-valia. Isso mostra apenas que há organizações que têm agendas obscuras e contrárias aos objetivos, missão e valores que nortearam o processo da sua criação, ou seja, as comunidades rurais e os camponeses, em particular, são usados como um trampolim para acumulação privada do capital. As organizações da sociedade civil e associações de camponeses moçambicanas vendo que as suas súplicas estavam sendo ignoradas pelos executores do ProSAVANA, intensificaram as suas ações mobilizadoras por forma a parar com as atividades deste programa.

Neste processo, escreveram uma carta aberta e foi endereçada aos três governos (Moçambique, Brasil e Japão), onde destacavam a necessidade de parar-se com o ProSAVANA por forma a ouvir as demandas populares, sobretudo, dos camponeses. O ProSAVANA configura-se num dos programas mais contestados por camponeses desde que Moçambique tornou um Estado capitalista.

O surgimento da "Campanha Não ao ProSAVANA», em 2014, trouxe um novo dinamismo no processo de lutas e resistências contra a implementação do ProSAVANA no Corredor de Nacala. É a partir da «Campanha Não ao ProSAVANA» que as lutas e resistências contra o ProSAVANA globalizaram-se e começaram a fazer-se sentir também no Brasil e no Japão. Após integrarem-se na «Campanha Não ao ProSAVANA», os movimentos sociais brasileiros e japoneses, começaram também a questionar os seus governos as reais intenções de financiar e implementar o ProSAVANA em Moçambique, tratando-se de um modelo que teve impactos socioambientais negativos no cerrado brasileiro.

A atuação da "Campanha Não ao ProSAVANA», houve mudança de abordagem nos discursos que nortearam a elaboração do ProSAVANA. Atualmente, a "Campanha Não ao ProSAVANA» é constituída pelas seguintes organizações da sociedade civil: a Ação Acadêmica para o Desenvolvimento das Comunidades Rurais (ADECRU), a Comissão de Justiça e Paz da Arquidiocese de Nampula (CAJUPANA), a Comissão Diocesana da Justiça e Paz de Nacala (CDJPN), o Fórum Mulher - Coordenação para a Mulher no Desenvolvimento, a Marcha Mundial das Mulheres Moçambique, a Justiça Ambiental (JA!) - Amigos da Terra Moçambique, a Liga Moçambicana dos Direitos Humanos (LDH), a Livaningo e A União Nacional dos Camponeses de Camponeses (UNAC).

Inicialmente, a «Campanha Não ao ProSAVANA» era composta por muitas organizações sociais, mas algumas delas, ficaram pelo caminho. Algumas foram capturadas pela classe dominante e isto, deveu-se a estratégia de cooptação que era usada pelos executores do ProSAVANA, outras dizem que abandonaram por 
não concordar com a filosofia da lutas da "Campanha Não ao ProSAVANA», destacando que têm abordagem diferente, é o caso da Associação Rural de Ajuda Mútua (ORAM). A «Campanha Não ao ProSAVANA» tem vindo a organizar conferências triangulares, onde agrupa povos dos três países envolvidos na implementação do ProSAVANA (Moçambique, Brasil e Japão), como uma estratégia de lutas e resistências, pois é aí onde levantam a sua voz contra este programa.

Em 2018, teve lugar na cidade japonesa de Tóquio, a «IV Conferência Internacional dos Povos», aonde além de ter reafirmado a sua missão de levar acabo as lutas contra o ProSAVANA, a «Campanha Não ao ProSAVANA», decidiu juntar-se aos movimentos sociais brasileiros na luta contra o MATOPIBA, a nova fronteira agrícola em expansão nos cerrados brasileiros (cf. CATSOSSA, 2019). No entanto, em Abril de 2018, a «Campanha não ao ProSAVANA» fez um pronunciamento depois de terem vazado informações sobre o encontro realizado na cidade de Maputo onde os três governos decidiram para avançar com a implementação do ProSAVANA, denunciando a falta de diálogo e transparência dos mesmos.

As lutas sociais organizadas e internacionalizadas contra o ProSAVANA, resultaram no cancelamento temporário das atividades do ProSAVANA. Esta é, portanto, uma vitória histórica considerando a forma autoritária e arrogante de como este programa foi sendo implementado ao longo do Corredor de Nacala. Pela primeira vez, os movimentos sociais moçambicanos conseguiram frustrar os interesses do(s) governos da FRELIMO, pois é quase impossível contrariar uma decisão tomada ao mais alto nível da nação. O que significa que querendo ou não, os povos deve seguir as ordens vindas do "topo", mesmo que estas, signifique uma ameaça a reprodução social do campesinato.

Contudo, a «Campanha Não ao ProSAVANA» entra na história como um movimento rebelde que fez sua história e política no campo no meio de tantas adversidades, caracterizadas por intimidação, opressão, agressão (física e psicológica), cooptação e entre outros aspectos, interrompendo temporariamente um programa fundando por princípios da acumulação primitiva do capital e/ou pela acumulação por espoliação. Mesmo de forma temporária, foi uma vitória, pois trata-se de um modelo pautado na separação sociedadenatureza e na mercantilização e pilhagem dos elementos desta última. Um modelo que espolia não só os territórios (i)materiais, mas também, todo o modo de vida dos povos e com eles, os seus saberes, sabores e seus valores.

Outrossim, é um modelo pautado pela dominação e controlo monopolístico do território, enfim, um modelo agrário/agrícola constituído na base do sistema-mundo moderno-colonial em que a técnica é a base para a materialização das relações de poder e de dominação. Trata-se, portanto, de um modelo baseado na geopolítica da fome, cujo objetivo é atender os interesses geopolíticos de commodities à escala global, enfim, 
um modelo agrário/agrícolas disfarçado do discurso desenvolvimentista, mas que promove a grilagem internacional de terras para acumulação privada do capital em escala global.

Mesmo que venha ocorrer a implementação efetiva do ProSAVANA, a verdade é que a «Campanha Não ao ProSAVANA» com o apoio das organizações sociais brasileiras e japonesas, conseguiram frustrar os executores deste programa. Como se sabe, as matemáticas dos executores do ProSAVANA era que a implementação efetiva deste programa começasse em 2015, mas ainda não "descolou" completamente por conta da força da «Campanha Não ao ProSAVANA» e seus parceiros de luta.

\section{CONSIDERAÇÕES FINAIS}

Embora o Brasil ao afirmar que, ao direcionar a sua política externa para o Sul global era uma forma de descentralizar as ações com vista os países do sul a desenvolver sem depender exclusivamente dos países do Norte global, pautadas em práticas expropriatórias, contraditoriamente, por meio da Cooperação Sul-Sul, o Brasil reproduziu exatamente a mesma coisa. Moçambique acabou sendo dependente do Moçambique em muitos aspectos, entre elas, a tecnologia para a modernização da agrícola, como também dinheiro para financiar a construção de diversas infraestruturas, sobretudo, barragens; doações de bens materiais, como, por exemplo, aviões e entre outros aspectos.

Por sua vez, as práticas exploratórias foram reproduzidas e a este fenômeno, está também a apropriação das riquezas caracterizada pela expropriação e expulsão dos povos dos seus territórios, desencadeado pelo capital brasileiro. O exemplo clássico disto, é a mineradora brasileira Vale Moçambique que explora carvão mineral na vila de Moatize, na província de Tete. Neste local, milhares de famílias camponesas foram expropriadas e expulsas dos seus territórios e, mais reassentadas em outros lugares. Estes povos, foram divididos com base no "estatuto social", onde se dizia que, quem sempre se familiarizou com a cidade, deveria permanecer nela e/ou próximo dela.

Já outros, foram Ihes negado o "direito a cidade" se emprestarmos as palavras de Henri Lefebvre. Estes, foram encaminhados para locais longínquos, onde para vir a cidade tornou-se um problema por conta dos preços de transporte serem elevados. No caso destes, dizia-se que, quem levou a vida capinando (trabalhando a terra), deve ir para onde pode continuar com esta atividade, como se o camponês não tivesse qualidade de viver na cidade. No entanto, a expropriação ainda não acabou, pois a Vale está a expandir as suas atividades para outras áreas, o que quer dizer que, milhares de famílias ainda serão expropriados e expulsos das suas terras para dar lugar a acumulação ampliada do capital em escala global. 
Além de Moatize, em Tete, a Vale expropriou e expulsou centenas de famílias das suas terras ao longo do Corredor de Nacala durante a ampliação da linha férrea. Algumas destas famílias, foram reassentadas outros lugares, mas forçados a levar uma vida urbana, a qual contrasta com a que tinha nos seus locais de origem. Além disto, as terras que foram Ihes entregue em compensação as anteriores, são improdutivas, situação que coloca estas famílias na linha da pobreza.

A territorialização do ProSAVANA em Moçambique, precisa ser vista como parte das contradições da Política Externa Brasileira, camuflado por discursos desenvolvimentistas e "culturista", baseado no paradigma de "perdão da dívida histórica" ao nível do continente africano, conduzida durante os governos "petistas", iniciada com o governo Lula (2003-2010), tendo sido continuada com a entrada no poder da ex-presidente Dilma Rousseff (2011-2016). O Brasil usou o discurso "desenvolvimentista", "produtivista" e "cultural" para esconder a verdadeira face da sua política externa.

O objetivo do Brasil, era o mesmo de outras potências imperialistas, ocupar e explorar terras agrícolas, e por via disto, empreender o controle monopolístico e especulação territorial por via do agronegócio. Fica evidente que o ProSAVANA representa interesses do grande capital e não necessitante dos camponeses locais. A entrada do ProSAVANA, em parte é resultado do fracasso das políticas e estratégias de desenvolvimento do setor agrários concebidos pelo governo moçambicano. A sua consolidação em Moçambique como programa, resulta ainda da conivência do Estado ao capital nipo-brasileiro, onde através dele, prevê-se a modernização rápida da agricultura moçambicana e por via disto, aumentar a produção e a produtividade agrícola do país.

Do lado brasileiro e japonês, ambos querem fazer do Corredor de Nacala, uma "réplica" do cerrado brasileiro, transformando Moçambique num “império da soja” ou ainda numa "superpotência mundial do agronegócio", na medida em que querem ocupá-lo para através dele e de sua gente como mão-de-obra barata, avançar com o processo de acumulação primitiva do capital. Nos últimos anos, o Brasil tem-se mostrado indiferente no processo de implementação do ProSAVANA. Além de ter transferido a equipe da Agência Brasileira de Cooperação $(A B C)$ e da Empresa Brasileira de Pesquisa Agropecuária (EMBRAPA) que trabalhava em Moçambique no contexto da implementação do ProSAVANA para Brasília, cortou vários financiamentos para as atividades relacionados com este programa. Estas atividades, passaram a ser financiadas pelo Japão por meio da JICA.

Por estar movido cegamente pelo preconceito e ódio contra pobres e dentro e fora do Brasil, inclusive, dos países (e dos povos) africanos e subordinado aos EUA, dentre outros motivos, existem possibilidades do governo brasileiro sob liderança de Jair Bolsonaro não dar atenção ao ProSAVANA. No entanto, esse resfriar das relações Brasil-Moçambique, adicionado a este preconceito e ódio, leva a crer que, o ProSAVANA poderá não ter apoio significativo do governo brasileiro. Mesmo assim, não significa que a "grilagem" internacional 
de terras em Moçambique desencadeada por empresas brasileiras vai cessar, muito pelo contrário, este fenômeno é inerente ao processo de reprodução ampliada do capital em escala global.

Contudo, o ProSAVANA, enquanto modelo de produção, é uma ameaça a agricultura camponesa que é predominante no Corredor de Nacala e com ele, a soberania alimentar/territorial e consequentemente, a segurança alimentar e nutricional dos povos locais. Com isso, o PRODECER enquanto modelo de produção, não pode ser referência para Moçambique, pois dele, apenas surgiu uma "modernização danosa" em termos socioambientais no cerrado brasileiro. O ProSAVANA coloca em risco milhares de famílias camponesas, primeiro, de expropriação e expulsão das suas terras e segundo, de destruição dos traços tradicionais que ainda são conservados e/ou preservados pelas famílias camponesas ao longo do Corredor de Nacala.

As associações camponesas e as organizações da sociedade civil têm um grande desafio e passa necessariamente por traçar novas estratégias de lutas e resistência com vista a barrar duma vez por todas a implementação efetiva do ProSAVANA, caso não, então a destruição do campesinato está dada. O desafio maior, vai para a "Campanha Não ao ProSAVANA» que além de ter se institucionalizado, ela se internacionalizou como um movimento social que está contra a implementação efetiva deste programa em Moçambique.

\section{REFERÊNCIAS}

AGUIAR, Diana \& PACHECO, Maria Emília (Orgs). A cooperação Sul-Sul dos povos do Brasil e de Moçambique. FASE/Brasil, Rio de Janeiro, 2016.

CACHAT, Severine. Ilha de Moçambique: uma herança ambígua. Alcance Editores, Maputo, 2018.

CATSOSSA, Lucas Atanásio. Discursos e realidades do agronegócio: do PRODECER no cerrado brasileiro ao ProSAVANA no Corredor de Nacala em Moçambique. Dissertação (Mestrado em Geografia), UFGD, MS, 2017.

CATSOSSA, Lucas Atanásio. Natureza apropriada, vidas cercadas: um olhar sobre o

Corredor de Nacala em Moçambique. In ALINE, Mara Ribeiro \& MORETTI, Edvaldo César (Orgs). Olhares geográficos sobre paisagem e natureza. 1a edição, Editora: ANAP, p. 83-123, São Paulo, 2018.

CATSOSSA, Lucas Atanásio. ProSAVANA em Moçambique e MATOPIBA no Brasil: a base para a compreensão da geopolítica da questão agrária na contemporaneidade. Revista NERA, v. 22, n. 47, p. 382-412, dossiê MATOPIBA, 2019.

CHICHAVA, Sérgio \& DÚRAN, Jimera. O Brasil na agricultura moçambicana: Parceiro de Desenvolvimento ou usurpador de terra? In: BRITO, Luís. et al., (orgs.). Desafios para Moçambique 2015. IESE, p. 297-415, Maputo 2013.

CHICHAVA, Sérgio. Moçambique e a crise político-econômica brasileira. In: BRITO, Luís et al., (Orgs.). Desafios para Moçambique 2017. IESE, p. 381-391, Maputo, 2017.

CLEMENTS, Elizabeth Alice \& FERNANDES, Bernardo Mançano. Estrangeirização da terra, agronegócio e campesinato no Brasil e Moçambique. UNESP/PP/SP, 2013.

CUBAS, Tiago Egídio Avanço. A questão agrária brasileira na era da globalização neoliberal. In: COELHO, Fabiano \& CAMACHO, Rodrigo Simão (Orgs). O campo no

Brasil contemporâneo: do governo FHC aos governos petistas. Editora: CVR, p. 217-241, Curtiba, 2018.

FABRINI, João Edmilson \& ROSS, Djon. Conflitos territoriais entre o campesinato e o agronegócio latifundiário. 1ạ edição; Editora: Outras expressões, São Paulo, 2014. 
FERNANDES, Bernardo Mançano. 27 anos do MST em luta pela terra. In: FERRANTE, FINGERMANN, Natalia Noschese. Os mitos por trás do ProSAVANA. In: IDelAS, IESE, Maputo, 2013.

FUNADA-CLASSEN, Sayaka. Fukushima, ProSAVANA e Ruth First: Análise de "Mitos por trás do ProSAVANA" de Natália Fingermann. OMR, Maputo, 2013.

HAESBEART, Rogério \& PORTO-GONÇALVES, Carlos Walter. A nova des-ordem mundial. Editora: UNESP, São Paulo, 2006.

JACINTO, Rui. Aparatos e aparências da lusofonia: Os sapatos sujos e seus labirintos. In: Geographia Opportuno Tempore, Londrina, v. 1, n. 2, p. 93-99, jan./ jun. 2014.

MACARINGUE, Ernesto Jorge. Modernização da agricultura no distrito de Monapo em Moçambique no contexto da redefinição da geopolítica da fronteira agrícola mundial entre 2004 a 2017. Tese (Doutorado em Geografia), UFG, Goiás, 2017.

MELO, Thiago Sebastiano de. OLIVEIRA, Adriano de \& BARBOSA JR., Ricardo. Cooperação sul-sul entre Brasil e Moçambique: de (in)segurança territorial à alteridade construída pela soberania popular. In: Revista da Associação Nacional de Pós-graduação e Pesquisa em Geografia (ANPEGE). ISSN: 1679-768X, p. 83-114, v.14, Mai./Jul, 2018.

MOSCA, João \& BRUNA, Natacha. ProSAVANA: Discursos, práticas e realidades. Documento de Trabalho, Observador Rural, OMR, Maputo, 2015

OLIVEIRA, Ariovaldo Umbelino de. Modernidade e Barbárie: as transformações no campo e o agronegócio no Brasil. In: Revista Terra Livre; ano 19, n. 21, jul./dez, p. 113-156, são Paulo, 2003.

PESSÔA, Vera Lúcia Salazar. O cerrado brasileiro e a savana africana no contexto das transformações no rural contemporâneo. In: FERREIRA, Alvaro; RUA, João \& MATTOS, Regina Célia (Orgs). Desafios da metropolização do espaço, Consequência editora, p. 443457, Rio de Janeiro, 2015.

PORTO-GONÇALVES, Carlos Walter. A globalização da natureza e a natureza da globalização. 7ạ edição, Editora: Civilização Brasileira, Rio de Janeiro, 2017.

SANTOS, Milton. Por uma outra globalização: do pensamento único à consciência universal. 23a edição, Editora: Record, Rio de Janeiro/São Paulo, 2013.

SANTOS, Roberto de Sousa. Políticas Públicas e o agronegócio na Amazônia legal/cerrado: Conflitos socioterritoriais. In: OLIVEIRA, Ariovaldo Umbelino de. et al., (Orgs). Território em conflito, terra e poder, Editora Kelps, p. 171-226, Goiânia, 2014.

SCHLESINGER, Sergio. Cooperação e investimentos do Brasil na África - 0 caso do ProSAVANA em Moçambique. 1a Edição, FASE, Moçambique, 2013.

UNAC. Pronunciamento da UNAC sobre o Programa ProSAVANA. Nampula, 2012.

VERA L.S.B \& WHITAKER, Dulce C.A (Orgs). Reforma agrária e desenvolvimento: desafios e rumos da política de assentamentos rurais. p. 27-52, São Paulo: Uniara, 2014. 